\title{
Are UK SMEs with Active Websites More Likely to Achieve Both Innovation and Growth?
}

\section{Piers Thompson}

Nottingham Business School, Nottingham Trent University, $8^{\text {th }}$ Floor Newton Building, Burton Street, Nottingham, NG1 4BU.

piers.thompson@ntu.ac.uk

\section{Robert Williams}

National Entrepreneurship Observatory, UK,

\section{Brychan Thomas}

Faculty of Business and Society, Glamorgan Business School, University of Glamorgan, Pontypridd, UK

"This article is $\odot$ Emerald Group Publishing and permission has been granted for this version to appear here (http://Ir.ntu.ac.uk/rpd/researchpublications. php?pubid=778bdbec-b0b4-4365-8fe5f6c7b9a05085). Emerald does not grant permission for this article to be further copied/distributed or hosted elsewhere without the express permission from Emerald Group Publishing Limited." - See more at:

http://www.emeraldgrouppublishing.com/authors/writing/author_rights.htm\#sthash.X augeO3s.dpuf

This paper has been published in the: Journal of Small Business and Enterprise Development: http://dx.doi.org/10.1108/JSBED-05-2012-0067

Please cite as following:

Thompson, P. Williams, R. and Thomas, B. C. (2013), "Are UK SMEs with active web sites more likely to achieve both innovation and growth?", Journal of Small Business and Enterprise Development, Vol. 20 No. 4, pp. 934-965. doi: DOI 


\title{
Are UK SMEs with Active Websites More Likely to Achieve Both Innovation
}

\section{and Growth?}

\begin{abstract}
Purpose

This paper examines the impact of developing more active Websites and increasing E-commerce on the relationship between innovation and growth performance in SMEs. Using the existing literature and empirical analysis the study considers the potential of engagement with the Internet to achieve the often hard to attain ambition of both innovation and growth.
\end{abstract}

\section{Design/methodologylapproach}

In order to examine the relationship, data is drawn from the Federation of Small Businesses (FSB) 'Lifting the Barriers to Growth Survey'. In order to establish whether the use of more sophisticated Websites is associated with being an innovative high performance business, whilst controlling for other firm and entrepreneurial characteristics, multivariate approaches in the form of multinominal logits and discriminant function analysis are utilised.

\section{Findings}

The results suggest that although theoretically Websites with tools allowing interaction with customers or suppliers could benefit SMEs through a reduction in transaction costs and wider access to information, enabling them to jointly experience innovation and growth, in practice there is less evidence that this occurs. If anything those firms with active websites are more likely to be innovative, but no more likely to be both innovative and achieving growth.

\section{Implications}

These results suggest that further work must be undertaken to establish whether SMEs should be encouraged to make such investments and if so what additional help is required to ensure that investments in this digital infrastructure achieves an appropriate return on investment.

\section{Originality/Value}

The results are of importance to both SMEs and policy makers providing insight into the nature of potential benefits from Website development using a large dataset. $A$ clear need to investigate further how more innovative SMEs can benefit from company Websites and ecommerce to grow is identified.

Keywords: Internet, E-commerce, Innovation, Growth, SMEs 


\section{Article Classification: Research Paper}

\section{Introduction}

It is often presumed that a more innovative orientation will increase the growth of small and medium sized enterprises (SMEs) (McAdam et al., 2004). This is because the ability of a firm to generate knowledge for innovation is increasingly viewed as one of the main determinants of competitive advantage (Freeman and Soete, 1997; Teece, 1998; Freel and Robson, 2004; Bilbao-Osorio and Rodríguez-Pose, 2004). This means it is usually assumed that innovation in SMEs is positively associated with stronger performance in terms of the growth of sales, employment, and profitability (Wigand, 1997; Freel, 2000). The evidence that such a relationship exists is not as clear cut (Freel and Robson, 2004). Some studies have found conflicting evidence whereby attempts to innovate disrupt the activities of businesses to such an extent that performance is put at risk (Christensen, 1997; Christensen and Raynor, 2003). Such effects are attributed to the resources that are required for innovation. These resource requirements could divert critical resources away from other day to day activities, which could put the survival of the firm at risk (Bergemann, 2005). Given this stretching of resources more risk averse managers will shy away from investments in new ideas (Souitaris, 2001). Thus, SMEs may achieve growth or innovation, but achieving both could be problematic.

Technological advances such as those associated with the Internet, however, offer methods of reducing transaction costs (Garicano and Kaplan, 2001). This could be both in terms of the innovation process and the firm's core production and sales activities (Wu and Hisa 2004; Wu and Hisa 2008; Beynon-Davies, 2010; Soto-Acosta et al., 2011). This can free up resources within the firm, allowing businesses to adopt a more innovative orientation that does not necessarily negatively influence the performance of the business. If such a link is present then this could have a considerable effect for increasing the level of economic growth through greater competitive advantage of UK SMEs (Wu and Hisa 2008; Soto-Acosta et al., 2011). It could also have ramifications for government policy that is already promoting the development and installation of the country's digital infrastructure, but would need to focus on providing the correct complementary skills within SMEs through associated training courses (Chaplin and Booth di Giovanni, 2010) and incentives for SMEs to innovate (Johnson and Drewett, 2011).

Using data from a survey of UK based SMEs, this study attempts to examine to what extent engagement with the Internet enables SMEs to maintain performance in terms of sales and profits growth whilst retaining the importance of R\&D investment within the SME. The data is drawn from the Federation of Small Businesses (FSB) 'Lifting the Barriers to Growth Survey' from 2008 and provides robustness to the research with over 4,500 observations, allowing the use of multivariate approaches. Multinominal logits are used to identify those characteristics associated with differing outcomes in terms of the combinations of growth and innovation. To clarify whether the use of more advanced Websites play a role in distinguishing innovative high performance SMEs from those achieving other outcomes, discriminant function analysis is also utilised. 
The remainder of the paper is structured as follows. Section 2 provides an overview of the literature considering SME growth and innovative activities. The literature relating to the relationship between innovation and SME growth performance is then scrutinised, before turning attention to the literature that outlines the benefits of the Internet in terms of reducing transaction costs for SMEs. This literature is utilised to outline the potential of company Websites in enabling smaller businesses to pursue innovation without putting current growth at risk. The FSB data is introduced in Section 3 along with the methods utilised in this study to investigate the presence of the theoretical links between the Website sophistication, innovation and growth. Section 4 outlines the empirical results of the study. The implications of these findings are discussed in Section 5. Section 6 provides conclusions and directions for future research.

\section{Literature Review: Innovation, SME Performance and the Internet}

There is considerable evidence that with greater globalisation and the loss of more protected markets, firms of all types will face greater competition (Zhu et al., 2006; OCED, 2010; Jehangir et al., 2011). In the face of such competition the need to innovate to remain competitive seems clear (Cefis and Marsili, 2006; Robertson et al., 2009). Studies such as those by Engel et al. (2004) and Roper (1997) have found strong links between innovation and firm sales growth. However, empirical evidence for the UK suggests that the links between innovation and performance are not necessarily simple and straight forward (Freel and Robson, 2004; Rosenbusch et al., 2011), and growth is not necessarily dependent on innovation (Edwards et al., 2001). This section outlines those studies that have investigated: performance and growth, innovation, and the complex relationship between the two within the SME context. The literature considering Information Technology (IT) adoption, specifically that associated with engagement with the Internet and Website development, is then considered to provide an understanding of how these investments may or may not allow SMEs to achieve both growth and innovation.

\section{Small firm growth}

Small firms are often identified as being sources of job creation and key players in terms of economic growth (Birch, 1987; Acs and Armington, 2004; Audretsch and Keilbach, 2004). Although, other studies have suggested that their role in promoting economic development may be over played (Parker, 2001), as studies often consider employment generation without accounting for the high level of job destruction within small firms (Davis et al., 1996). However, growth has also been found to be of importance for the SMEs themselves, being a key factor in determining the survival prospects of SMEs (Phillips and Kirchhoff, 1989; North et al., 1992; Huggins et al., 2012). This may reflect the fact that for many SMEs a heavy reliance on local custom can make them highly vulnerable to localised economic downturns such as the loss of a major employer, and competition from new entrants into once protected markets (Packham, 2002; Packham et al., 2005).

However, not all SMEs are growth and innovation orientated (Kirchhoff, 1996; Thompson et al., 2007), whilst others will be constrained by the key resources that they hold, particularly in terms of knowledge (Grant and Baden-Fuller 2004; : St Jean et al., 2008). It is the ability to absorb learning and accumulate knowledge in preparation for further stages of growth that determines whether a firm is able to 
progress to the next stage of development (Thorpe et al., 2005; Phelps et al., 2007; St Jean et al., 2008; Blackburn et al., 2008; Chaplin and Booth di Giovanni, 2010). For many SMEs this may mean absorbing information about new groups of customers as familiar local markets are unable to support further growth (Gorton, 1999; Blackburn et al., 2008). Consistent with this the skills and education of the entrepreneur have been found to be positively related to growth of SMEs by Cooper et al. (1994). However, the relevant source of human capital may differ depending on the relevant measure of performance being considered. Bosma et al. (2004) find that while higher levels of formal education along with experience within the specific industry positively boosts profitability it is employment experience alongside specific industry experience that have a significant influence when employment creation is considered. Colombo and Grilli (2005) in their study of young Italian technology based firms also suggest that the benefits of university education may be subject dependent, with economic and managerial fields providing the greatest benefits, followed by more scientific and technical subjects, whilst no significant gains are obtained from university education in other subject areas.

Graduate entrepreneurs as well as potentially possessing more knowledge themselves are also found to have access to a wider variety of information sources (Pickernell et al., 2011). In particular links to knowledge institutions such as universities could boost growth (Clifton et al., 2010). Pickernell et al. (2010) find that those SMEs with links to universities may benefit in terms of growth through improved skills and network development, although controls are not included to account for other characteristics of the businesses, such as industry sector or owner's education to establish the full nature of the benefits received from this relationship. Even where studies have accounted for firm characteristics, such as age, size and sector, Macpherson and Holt (2007) suggest that these categorisations are not nuanced enough to accommodate the idiosyncratic learning experiences leading to growth found by previous studies.

\section{Innovation}

It is clear that long term success comes from a firm's ability to adapt to changes in customers' needs and to provide the goods and services required in a flexible and efficient manner (Twari and Buse, 2007; Soto-Acosta et al., 2011; Hansen and Hamilton, 2011). This explains the longer survival of more innovative SMEs (Cefis and Marsili, 2006).

Although innovation is linked to retaining competitiveness and ultimately survival (Cefis and Marsili, 2006; Robertson et al., 2009), rather than innovate and grow, Storey (1994) finds that many firms are content to stand still and survive. Whilst this could clearly reflect differences in terms of measures of business success (Zhu and Kraemer, 2002), such as lifestyle choices (Blackburn et al., 2008) compared to the traditional sales growth and profitability measures, if the survival and perpetuation of such lifestyle benefits are put at risk by not innovating this would seem strange. However, resources within SMEs are frequently extremely scarce and innovation is not guaranteed to be successful (Bergemann, 2005), in addition investments in innovation exhibit a degree of irreversibility (Bougrain and Haudeville, 2002). In the context of a large proportion of firms' capital being staked with no method of retrieving this investment, risk averse managers are likely to be deterred from following more innovative strategies (Souitaris, 2001). This means the number 
of innovations actually developed by SMEs is likely to be relatively low, and most of those developed will be minor incremental innovations (Nooteboom, 1994).

The human capital available within the firm is likely to be a crucial factor in successful innovation (Frughling and Siau, 2007). Although human capital possessed by the workforce as a whole is likely to have a role to play (Hoffman et al., 1998; Blackburn et al., 2008; Zucchella, 2009), that of the owner-manager is likely to be of particular importance (Romano, 1990). This will not just be in terms of the skills and knowledge that this implies, but also the access to a wider variety of quality sources of advice as well (Pickernell et al., 2011). Interestingly however, Pickernell et al. (2010) find no significant link between contacts with universities and development of existing or new products or processes. Clifton et al. (2010) do find that university contacts have a greater impact on innovation when geographical proximity is controlled for. Local universities appear to play an important role in creating general innovative capacity. However, networking to boost innovation may be more risky for smaller SMEs as they risk being dominated by their larger partners (Porter, 2004).

In order to promote innovation Humphreys et al. (2005) suggest that it is the culture of the organisation which is more important, rather than the organisation being simply aware of new products, technologies and processes. McAdam et al. (2010) develop a model of innovation implementation for SMEs and test this with the use of structural equation modelling (SEM). They find that an open culture within an organisation is key in generating innovation leadership, this feeds into the product and process development management within the organisation, which in turn is positively linked to successful innovation implementation. A culture needs to be developed that is not overly managed, but encourages those within the organisation to undertake appropriate risky and creative activities, through the provision of management support and resources (Judge et al., 1997). Although it is difficult to measure the extent to which an innovative culture is created within an SME there are likely to be links to the importance that managers place on research and development activities (Khan and Mattapichetwattana, 1989; Verhees and Meulenberg, 2004; Laforet and Tann, 2006), which is the approach used within this study to measure innovative orientation of firms.

\section{The relationship between innovation and growth}

The benefits of innovation in terms of survival and growth may seem obvious for SMEs, with a more proactive approach to innovation helping to create new market niches, which is linked to improved performance (Hadjimanolis and Dickson, 2000; Blackburn et al., 2008). Particular examples of such successes have been identified in the high technology sectors including software and biotechnology (Romijn and Albaladejo, 2002). However, even in technology dominated sectors, where innovation might be thought to be of paramount importance, other studies have found it to only strongly influence growth for a minority of businesses (Coad and Rao, 2008). Instead, Dibrell et al (2008) suggest that an innovative orientation has no direct influence on firms' performance measured by profitability and growth relative to that of rivals, other than where it encourages the adoption of information technology enabling closer monitoring and response to rivals. This means generally this relationship between innovation and growth has been found to be relatively weak (Cooke et al., 2005). Some studies have even suggested that attempts and activities 
associated with innovation, such as, knowledge networking can be detrimental to the growth of businesses (Huggins and Johnston, 2009).

One explanation for this weak relationship between activities associated with innovation and SME performance is the limited resources that are available for SMEs (Hewitt-Dundas, 2006). SMEs can be held back in terms of both financial and human resources (Black, 2004). Any engagement with innovative activities will of course require resources to be diverted from other activities within the business, which explains some of the negative relationships previously found with overall firm performance, particularly in the short-run (Heimonen, 2012). This could mean SMEs can either grow or innovate, but not necessarily both. Potentially this could be a bigger problem within more mature firms where resources become more specialised and less flexible (Amit and Shoemaker, 1993). Rosenbusch et al. (2011) in a metaanalysis found that new firm studies indicated a positive relationship between innovation and performance, suggesting that a lack of resources was not a problem for this group of firms, but it is unclear from their study whether this would be the case for more mature, but still smaller SMEs.

The previous studies suggest that the relationship between innovation and performance in SMEs may vary by industry (Rosenbusch et al., 2011). For example Freel and Robson (2004), find evidence of positive relationships between innovation and growth for service firms, but the opposite relationship for manufacturing firms, potentially reflecting the lag that manufacturing firms face before obtaining a return from their investment.

\section{The role of the internet in the innovation and growth relationship}

The Internet might provide a tool to retain and even strengthen an innovative orientation, whilst avoiding putting growth at risk. Studies examining the Internet and SMEs have suggested that it will allow a much greater collection and processing of information than was previously possible (Mathews and Healy, 2007; BeynonDavies, 2010). This can aid innovation through a greater understanding of the evolution of customers' needs (Koschatzky et al., 2001; Soutaris, 2001; Roach, 2011; Huang and Tsai, 2011). Interactive Websites that enable more intelligence gathering and more frequent and timely interaction with both customers and suppliers are likely to be particularly beneficial to micro enterprises where such market intelligence capabilities are usually weak (Smeltzer et al, 1988; Verhees and Meulenberg, 2004).

The greater use of the Internet also increases the innovative orientation of SMEs in a more indirect manner. Rather than acting as a greater source of information relating to consumer needs and supplier developments, the Internet through the use of company Websites enables SMEs to reduce more traditional transaction costs (Garicano and Kaplan, 2001; Huang and Tsai, 2011). As such, technological developments, which aid SMEs in terms of intelligence gathering and reducing transaction costs elsewhere in the business (Huang and Tsai, 2011), could have benefits in enabling SMEs to enjoy both growth and innovation, by freeing up greater resources to commit to innovative activities.

Equally for more innovative businesses that were previously unable to pursue growth strategies through a lack of resources, one of the main perceived advantages of the Internet and e-commerce is enabling SMEs to reach customers more widely (Dutta and Evrard, 1999; Williams et al., 2010; Roach, 2011). For innovative firms developing niche products this is likely to be of particular value, as such markets are 
likely to be thin and widely spread (Hamill, 1997; Napier et al., 2001; Levy et al., 2002). However, the extent to which these advantages are realised is limited by the extent to which there are Web skills present within SMEs (Lawson et al., 2003; Weltevreden and Boschma, 2008). For firms looking to use more sophisticated Website functions to reduce transaction costs, these shortages are likely to become more acute particularly in regard to more advanced skills (Thompson et al., 2010).

The literature presented above suggests that the resource scarcities experienced by SMEs may make growth and innovation an either/or proposition. However, new technologies such as the Internet and more advanced Websites in particular could provide a means to use resources more efficiently allowing the twin aims to be achieved, however, limited capabilities specifically related to information technology may limit its potential. Section 3 below outlines the FSB data and methods used to explore to what extent a positive link does exist between greater use of company Websites by SMEs and the ability to adopt an innovative orientation whilst still retaining a strong growth performance.

\section{Data and Methods}

In order to investigate the use of company Websites by SMEs and their influence on the relationship between innovative orientation and performance we utilise data from a recent Federation of Small Businesses (FSB) 'Lifting the Barriers to Growth Survey' from 2008. The reasoning for using the FSB survey is that it is the largest small business trade association in the UK, with approaching 200,000 members. The FSB survey is conducted on a biennial basis with surveys sent to all members of the Federation, with the alternative of an identical electronic version of the survey made available through their Website. The survey was originally mailed early in 2008 with a number of reminder emails sent out directing respondents to the FSB Website where the electronic version of the questionnaire was accessible. A formal pilot was not conducted due to the determination of the types of questions and suitability of language having been developed previously. The survey covers a wide range of issues relating to the membership of the Federation and therefore does not specifically deal with the use of Websites and e-commerce by their membership. It does provide a relatively large sample size, with over 4,500 observations available. The data also covers a large number of firm and owner characteristics that can be used to control for the resources available to the SME. However, the survey does include some specific items relating to Internet based topics, which were deemed appropriate to this study. Included within these is a question which seeks to determine whether the firm has a Website and if so what actions the functions of the Website allow customers and suppliers to undertake. This was stated as follows:

"Does your business have a Website, and if yes, what is it used for?"

The respondents are asked to select one of the options from those listed below that best describes their current Web presence.

1. No

2. Yes, but only for basic contact information

3. Yes and it is used to advertise our products

4. Yes and it is used to advertise and sell our products on-line

5. Yes and it is used to link to suppliers 
6. Yes and it is used to link to suppliers and sell our products on-line

A vast majority of those with Websites are in the lower orders of Website functionality (see tables A1 and A2 in the appendix for summary statistics of all dependent and independent variables respectively). This makes it necessary for data to be aggregated by Website functionality into non-adopters (those with no Web presence at all, group 1), non-active Website users (those with Websites not providing tools for interaction with customers or suppliers, groups 2 and 3), and active Website users (those using Websites for purposes of e-commerce, linking to customers, suppliers, or customer and suppliers, groups 4, 5 and 6).

An additional measure of the extent an SME embraces the Internet is the proportion of sales that the company attributes to e-commerce. This is a selfreported measure of the percentage of total sales that SMEs achieved through ecommerce sales. Although such a link only relates to the transaction costs associated with serving customers, rather than those associated with dealing with suppliers it is included as an alternative measure. As with the functions incorporated into Websites, the reliance on e-commerce, as measured as a percentage of the firm's total sales, is dominated by responses towards the lower end of the scale. Given that the percentages reported were likely to include some measurement error, the firms were grouped into three groups, those with no sales attributed to ecommerce, those with minimal reliance on e-commerce sales (10 percent or less of total sales), and those with moderate and high reliance of e-commerce (more than 10 percent of sales).

The measures used to reflect performance are the self-assessed sales and profit growth rates from the preceding two years. Firms were asked to indicate the range of change in profits that most accurately reflected their experience over the last two years, and similarly for changes in sales. In order to concentrate on those firms experiencing more rapid growth over this period, firms with sales growth of more than 20 percent are defined as high growth firms in terms of sales. Those firms displaying strong profits growth were defined as those with increases in profits over the two year period of more than 10 percent. Although there is likely to be a strong correlation between the two measures it is unclear to what extent one can be achieved without the other (Davidsson et al., 2009).

As noted in Section 2 identifying innovative activities in SMEs is likely to be relatively difficult. Studies of larger firms sometimes utilise outputs of the process, such as patents and new products as measures of innovation (Acs and Audretsch, 1989; Acs et al., 2002; DTI, 2006). This is less likely to be appropriate for most SMEs included within the sample, where Kitching and Blackburn (1998) found previously that more informal methods such as keeping trade secrets were preferred to patent protection. Therefore, following the work of Judge et al. (1997) we instead use a measure of the importance of innovation within the business over the previous two years. The measure used was the importance placed on increasing R\&D spending. Although the item in the survey does not make it clear whether such an objective was achieved it does isolate those businesses where such activities are prioritised to a greater extent and a more accommodating climate for such activities is likely to be present. The item was measured on a five point Likert scale running from 1 not important to 5 very important. Those indicating 4 or 5 on the scale were defined as innovatively orientated businesses. Rosenbusch et al.'s (2011) meta- 
analysis suggests that measures of this type, which are more closely associated with a strategic orientation towards innovation in general rather than being a more specific measure concentrating on the development of products, are more likely to have a positive relationship with growth.

As discussed below in more detail the growth and innovative outcomes of SMEs will be influenced by a number of factors. This means to isolate the impact of the Internet based variables a multivariate approach is adopted, with independent variables utilised to control for the other influences. The sample available varies in size depending on whether the Website or e-commerce approach is utilised to represent the engagement with Web based technologies. Under the Website based approach to a sample of 5,982 firms is available with data for all dependent and independent variables. For the e-commerce based sales the sample available is 4,786 firms.

By defining firms in this manner three binary variables were created. Two of these relate to growth, one based on profits and the other on sales. The third relates to the presence or not of an innovative orientation. This allows the firms to be grouped into four categories across the two dimensions under investigation, growing $v$ non-growing, and innovative orientation $v$ non-innovative orientation. This categorisation is shown in Figure 1 below. 
Although the ideal is for firms to be in the bottom right quadrant, where growth is relatively high and there is an orientation towards innovation, it is not clear from the literature that such a strong relationship exists between innovation and performance. Studies, such as, Christensen and Raynor (2003) that suggest that the low resource availability of SMEs could see innovation act in a disruptive manner. This might suggest that SMEs really have to choose between the bottom left and top right quadrants, either targeting growth or innovation respectively. This study seeks to identify whether the use of an interactive company Website enables firms to overcome this trade-off and move from successful achievement of outcomes in one dimension to that within both.

To examine this relationship a multivariate approach is adopted. This allows the human, social and physical capital available to the firm, which are likely to be key inputs in achieving both growth and innovation (OCED, 2010), to be controlled for. In most cases these will be represented by scale of the firm and the characteristics of the entrepreneur. Standard ordinary least squares regression is not appropriate, as the dependent variables are nominal in character rather than continuous. This means that a multinominal logistic regression approach is adopted. This approach allows the influence of individual characteristics on the probability of belonging to a group of firms to be identified compared to belonging to a base category. In the analysis here the base category chosen is 'growth with no innovation' represented by the bottom left quadrant of Figure 1. This group is chosen as the base category to allow comparisons between what may be a standard measure of success with other measures associated with innovation. The analysis will therefore help to establish whether the Website related variables are associated with innovative outcomes relative to growth only related outcomes. Each estimation will produce three sets of regression coefficients reflecting the influence of each independent variable on the probability of belonging to each of three other groups relative to this base group.

As the same characteristics may be associated with both growth and nongrowth innovative outcomes, as a follow-up analysis we also utilise discriminant analysis to help to isolate those characteristics associated with firms found in the bottom right quadrant of Figure 1 (Klecka, 1980). Discriminant analysis (DA) involves discriminating between groups to classify dependent variable(s) or, in this case, best predictors of differing SME outcomes defined by combinations of growth and innovative orientation. Discriminant analysis, rather than identifying those variables related to the probability of belonging to a group, identifies those variables that make groups most distinct from one another, so the distance between groups is maximised. The analysis splits the groups along a number of dimensions up to $G-$ 1 , where $G$ is the number of groups in the analysis. In this case, the analysis calculates up to 3 functions to split the groups. One function may be better at splitting those firms belonging to one outcome group from those belonging to the other groups, but in order to identify members of all groups the functions are used in combination. The functions estimated can then be used to generate discriminant scores for the individual observations in order to categorise them into the groups. The variables that help to identify members of each group can be identified through the canonical coefficients and the group centroids (mean discriminant scores for each group). If the group centroid for a function is positive (negative) those variables with large positive (negative) coefficients will be those that help to identify members of that group most strongly. 
As only a small number of the variables are likely to discriminate between groups, we use a stepwise approach only entering those variables which have a significant influence on improving the analysis. The criterion for inclusion in the model is based on the partial $F$ statistic with only those excluded variables included in the next stage, where the improvement in discriminative power is significant at the 5 per cent level. The most significant variable is included at each stage. Those variables not selected to enter in each step are examined for significant contribution in the next step, with a variable entering at each step until a step occurs where no variable significantly improves the analysis. Although it is likely that the most influential variables will be similar regardless of the dependent variable utilised (sales or profits based measure of growth), the less influential firm and entrepreneurial characteristics may differ, with only those selected as having a significant influence included in each.

Independent variables (IVs) included in the analysis are drawn from previous studies where they are suggested to be associated with either stronger firm performance or innovation (Bewley et al., 2010). In most cases the data takes the form of nominal or ordinal variables. To include them in the regression analysis, each category is represented by a dummy variable, with one category withheld from the analysis to act as the base category to which the other categories are compared to.

Given that a lack of resources have been identified as one of the reasons for low innovation in SMEs (Hewitt-Dundas, 2006), higher and lower levels of turnover are included as independent variables (turnover of less than $£ 100,000$ and turnover of more than $£ 500,000$ ). As well as financial capital the low absorptive capacity of SMEs is also identified as a barrier (Beijerse, 2000). Although the availability of human capital within the firm is not restricted to the owner-manager of the business, some studies have suggested that understandably they do play a key role (Hoffman et al., 1998), although this is not the case in all studies (Keizer et al., 2002). Following the convention of many empirical studies human capital is measured imperfectly through formal training (represented by qualifications) and experience (represented by age) (Blundell et al., 1999; Bosma et al., 2004). Where a positive effect might be found is where these can reflect the access to external resources in terms of advice from the greater social capital that more highly educated entrepreneurs possess (Pickernell et al., 2011). As studies, such as Phelps et al. (2007) and Romano (1990) note the importance of acquiring and absorbing information to grow and innovate the fact that more highly educated entrepreneurs have been found to develop networks that enable access to a wider variety of knowledge (Yli Renko and Autio, 1998; Yli Renko et al., 2001) is likely to be highly important. Linking into the role played by the Internet Lee and Jones (2008), also find that more highly educated owners are also more successful in leveraging new forms of information communications technology (ICT) to access information through networks. Although the FSB data does not provide data on the subject of study, different style and level of qualifications of the owner-manager can be included in the analysis (no formal qualifications, vocational, compulsory secondary, graduate, postgraduate and professional qualifications). As well as formal education, experience particularly concentrated in a particular field, can also be an important source of human capital (Marvel and Lumpkin, 2007), but others have found contrary evidence (Koellinger, 2008). This reflects the rising value of time with age, which encourages some to seek the immediate returns of employment over business ownership (Lévesque and Minniti, 2006). Similarly it is understandable that older business owners prefer the relatively immediate returns of a non-innovative 
business, over an innovative business with a longer gestation period (Audretsch, 2004). Within the regressions age is allowed to enter as a continuous variable centred around the mean age of the sample. To allow for a non-linear relationship a squared version of this centred variable is also included. Centring the variable makes the zero value more meaningful and also reduces issues of collinearity with the quadratic term (Cohen et al., 2003). Within the discriminant analysis it may be more useful to observe if particular age groups are associated with the growth and innovation group of firms and therefore dummies to represent owner-managers in the age groups 18 to 35 years; 45 to 54 years; 55 to 64 years; and 65 years and older, are included. Gender differences may also be present with, on average, innovative and financial outcomes are found to be of lesser importance as measures of success for female entrepreneurs (Carter et al., 2003). Dummies to control for male and female dominance of ownership are included to capture this.

Younger firms have greater flexibility with their routines less deeply embedded (Knight and Cavusgil, 2004). In combination with the reduced benefits of scale economies in recent years (Wennekers et al., 2005), younger firms are therefore better placed to pursue a more innovative approach. Dummies are included to represent the youngest firms (less than four years) and older more established firms in the sample (10 years or more). As innovative orientation and growth of SMEs are likely to vary considerably by sector (Nooteboom, 1994), dummies are included to represent the type of firm, although quite broadly at the Standard Industrial Classification (SIC) 1 digit level (Prosser, 2009). A dummy representing an urban location controls for differing market growth and networking opportunities (North and Smallbone, 2000).

\section{Results: Evidence of Innovation and Growth in UK SMEs}

The proportion of SMEs that are classed as high growth in terms of sales (+20 percent over the last two years), or profits (+10 percent over the last 2 years) is shown in Table 1 below. As other studies have found, the proportion of SMEs achieving high growth rates, both in terms of profits and sales, is relatively low. This may be because survival is the most important objective of many small firms (Storey, 1994). Similarly relatively few SMEs indicated they had an innovative orientation (rating the objective of increasing spending on R\&D as 4 or 5 on a five point scale).

Table 1 to go about here

The relationships between the growth and innovation measures are shown in Table 2 below. There is a large significant correlation between the growth measures. Firms with rapidly increasing sales are therefore also more likely to be increasing their profits. The correlations between innovative orientation and the performance measures are consistent with studies such as Cooke et al. (2005) where a positive, but relatively weak link is found. Although, highly significant the size of the coefficient indicates that an innovative orientation does not guarantee that the firm will be growing. This weaker link is consistent with growth from innovation occurring after a period of time and therefore the relationship ideally should be considered over a longer time frame (Freel and Robson, 2004).

Table 2 to go about here 
In fact only 27.3 percent of those firms, which are classed as innovatively orientated also achieve high sales growth, and 24.5 percent of these innovative firms experience high profits growth. This means that only just over 2 percent of the whole sample are innovatively orientated and at the same time achieving growth in terms of profits or sales (2.4 percent are innovative and have high sales growth, 2.1 percent are innovative and have high profits growth).

Table 3 below presents the results of the multinominal logit regression estimates when using the Website based measure. Although the pseudo $R^{2}$ values indicate that only a small proportion of the deviation is explained by the regressions, the likelihood ratio tests indicate that all regressions out-perform the null of constant probability at the 1 percent level. In addition, the likelihood ratio tests also indicate the null of the Website variables being collectively insignificant can also be rejected at the 1 percent level.

Table 3 to go about here

The results indicate that possessing an active Website makes a firm significantly more likely to be innovatively orientated than just increasing profits rapidly. An active Website increases the probability of innovation both in the presence of high profits growth and in its absence relative to the base category of increasing profits rapidly alone. A lack of a Website is negatively related to the two innovative orientation outcomes and positively associated with no growth and no innovation. The pattern of association between possession of an active Website with innovation is less clear when growth is measured by sales. Here an active Website only increases the probability of a firm experiencing both sales growth and innovation relative to sales growth alone.

Another influence on the probability of being innovation orientated is the size of the firm. Smaller firms are less likely to be innovation orientated relative to achieving growth alone. This may reflect the physical capital available for innovative activities within larger firms (Zhu et al., 2006; Hodges, 2010; Macredie and Mijinyawa, 2011). A similar pattern is found for the age of the firm. Although young firms are less likely to be neither growing or innovating, they are also less likely to be growing and innovating at the same time. Effectively, firms less than four years old are more likely to be concentrating on just growth rather than innovation. As firms develop rather than concentrating on growing (increasing sales in particular), they are more likely to either stagnate with no sales growth or innovation, or concentrate on innovation with no sales growth.

From a human capital perspective, postgraduate qualifications also increase the probability that a firm is innovatively orientated and growing rather than just increasing profits or sales. At the other end of the spectrum those with no formal qualifications are more likely to be innovation orientated rather than growth orientated, but this innovation is achieved in the absence of matching sales or profits growth. However, experience as captured by the owner's age increases the probability that a firm is neither growing nor intending to innovate, reflecting the lifestyle impacts outlined in section 3 (Audretsch, 2004).

Table 4 to go about here 
The regressions run using the e-commerce measure produce similar results for the other firm and entrepreneurial characteristics, but the percentage of sales associated with e-commerce is less strongly associated with the different firm outcomes. Those with no e-commerce sales are less likely to innovate in the absence of growth, and those with higher e-commerce sales are significantly more likely to increase sales and be innovatively orientated.

Table 5 presents the discriminant analysis results when using the Website sophistication measure. When growth is captured by either profits and sales the vast majority (over three quarters) of the explained variance is captured by the first function. The small Eigen values suggest that the functions are relatively inefficient at distinguishing the four outcome groups. Similarly the relatively low canonical correlation values suggest a weak link between the discriminant scores and the four groups. The Wilks' Lambda values indicate the proportion of all variation in the discriminant scores that remains unexplained by the functions is relatively high. However, the chi-square tests indicate that all three functions estimated have discriminatory power at the 10 percent level. Meaning that all three functions have value in splitting the firms into the four outcome categories.

For both measures similar firm characteristics were selected by the stepwise procedure. Firm size, and firm age were those variables selected firstly by the stepwise approach. Consistent with those studies indicating the education of the owner-manager plays an important role graduate and postgraduate qualifications are identified as having a role in discriminating between groups (Romano, 1990; Pickernell et al., 2011). Those variables representing the possession of an active website or no website are also selected.

The standardised canonical discriminant coefficients represent the individual contribution of selected variables towards the discriminant functions allowing their relative importance to be identified. The estimated discriminant functions are used with the characteristics of the firms in each of the outcome groups to estimate the group centroids (mean value of the discriminant score for a given category of the dependent variable). Given the differing signs on the group centroids for function 1 , this first function is best at separating the non-growing non-innovation orientated firms from the others. Here the positive coefficient for possession of an active Website is found to reduce the likelihood that a firm falls into the low growth no innovation group. The large coefficient on the variable representing young firms indicates that stage of development plays a particularly important role in separating this group of firms from the others that display growth, innovation or both.

Again considering the signs on the group centroids, function 2 is better at separating those firms that are growing, but show less evidence of an innovative orientation. Again the largest canonical coefficient is found for the dummy variable representing the youngest firms in the sample. Confirming the results of the multinominal logit, younger firms are more likely to be in the rapidly growing, but not innovative group. When considering those firms increasing profits, but not innovating, other influential variables are the dummies representing Financial Services who are more likely to belong to this group, and Manufacturers who are less likely to be in this group. Use of a Website to undertake transactions with customers or suppliers does help identify those firms not belonging to this group.

Considering the group centroids for the third function, which accounts for the smallest proportion of the explained variance, is best at separating those firms which are both innovatively orientated and growing from those which are not growing but innovative. This is evident from the differing signs on the two centroids. Under both 
measures of performance both the oldest and youngest firms are identified with low growth innovation. The small canonical coefficients suggest that unfortunately it appears that Website functions (as demonstrated by the study results) appear to have little role to play in overcoming the difficulties in maintaining an innovative orientation and continuing to grow when growth is measured by sales. When using the profit growth measure the negative coefficient on the active Website dummy variable makes firms more likely to be innovating with no profit increases rather than innovating with increasing profits. It is possible that efforts to maintain and update the Website actually creates more of a distraction and resource drain, consistent with Cohen and Kallirrol's (2006) assertion that in-house costs of the Internet are often under-estimated at the time of adoption. Human capital does appear to play a role in separating growing innovative firms from non-growing innovative firms (Pickernell et al. 2011), with university education associated with the growing innovatively orientated firms.

Table 5 to go about here

Table 6 to go about here

Table 6 above presents the discriminant analysis when the e-commerce sales measure is used. The group centroids suggest that the third function once again is best at separating those firms, which are innovative, but not growing from those that are innovative and growing. The canonical coefficients on the dummies representing a higher level of sales coming from e-commerce indicate that these firms are more likely to be innovative and growing than innovative and non-growing.

\section{Discussion}

This paper has examined the relationship between SME growth and innovative orientation. As with previous studies, such as Cooke et al. (2005), the study found for the sample as a whole, UK SMEs experience a positive relationship between innovative orientation and performance measured both in terms of higher sales growth and higher profits growth. Only a tiny minority of SMEs achieve both. The literature in Section 2 suggested that the costly disruptive nature of innovation may explain part of this (Zhu et al., 2006; Fruhling and Siau, 2007; Lee et al., 2010; Ordanini and Rubera, 2010). The possibility that interactive Websites may provide SMEs with the ability to undertake collaborative innovative activities, or simply reduce costs enabling both positive outcomes to be achieved was explored. Consistent with studies (such as Freel and Robson, 2004; Loof and Heshmatt 2006 and Hodges, 2010) analysis also suggested that many contextual factors such as firm age, firm size and industry play an important role in distinguishing this group of growing innovative SMEs from those that have an innovative orientation, but have not displayed any signs of benefiting from this innovation in terms of performance. Attempting to control for these factors through multivariate analysis the study found mixed evidence that using company Websites to conduct transactions with customers and suppliers enabled growth and innovation to be jointly maintained.

Use of interactive company Websites did help to identify those firms which were more innovatively orientated rather than simply growing without innovation. This link between company Websites and innovation is encouraging given the 
importance that studies, such as Wennekers and Thurik (1999) and Howells (2005) have placed on innovation for retaining regional competitiveness and employment growth. However, the study found this positive link often occurred with both innovative non-growing and innovative growing firms. There was some weak evidence from the discriminant analysis that active Websites help to separate the growing innovative from the non-growing innovative firms when considering the sales based measure. However, only a minority (31.2 per cent) of innovative firms with active Websites were classed as growing.

When considering changes in profits the opposite result to that which was expected was found, so that possession of an active Website made it less likely firms would be both growing and innovative. This means that there is a danger that this innovation, associated with the presence of active Websites, rather than securing the future of SMEs may in fact weaken these businesses and make them appear to be attractive takeover targets to secure intellectual property rights (Cosh et al., 1999). This means that the local economy may see little benefit in the form of job creation.

Given the literature linking the Internet, and Websites in particular, with reduced costs of accessing information and undertaking other business operations, that allows resources to be freed up for innovative activities without harming performance (Beynon-Davies, 2010; Huang and Tsai, 2011) what explanations are there for active Websites being negatively linked to firms being able to grow at the same time as they innovate? One explanation is associated with the costs of Website adoption itself. Although initial commitments required for Website adoption can be low, maintaining and updating a Web presence can absorb considerable managerial resources (Narula, 2003; Zhu et al., 2006). Although, the reason that firms with active Websites are less likely to be innovative and increasing profits cannot be ascertained from the results. The results are consistent with Websites distracting managers in some cases rather than enabling innovation (Fruhling and Siau, 2007).

The multinominal logit regressions produced similar results when considering an alternative measure of Internet engagement based on e-commerce sales. However, there was a positive link to increased profits for firms that were innovating when more sales were derived from the Internet. This is likely to reflect the more direct link to reduced transaction costs associated with day to day activities. Whereas the active Website measure represents the possibility of sales taking place through this channel, but not necessarily its success. This is reassuring for policymakers that have shown a high degree of confidence in the potential of the digital economy to regenerate more peripheral areas (Grimes, 2003).

Regardless of whether considering the results using the Website presence or sales through e-commerce measures, policy-makers and small business owners alike should not become obsessed with the potential of developing company Websites and e-commerce. Other factors such as firm age and industry sector did play a much stronger role. For example, the results here suggest younger firms are less likely to both innovate and grow, and therefore policies to promote survival will be of similar importance. Equally a regional economy where the fast growing business services sector is under-represented and is more heavily dominated by retailers also appears less likely to enjoy the benefits of both high growth and innovation. For owner-managers the importance of human capital is apparent from the positive influence of high qualifications on achieving both growth and innovation. This shows the importance of being able to not only acquire, but also absorb information (Pickernell et al., 2011). Again this suggests that general management 
training and in particular that associated with Website technologies should be a priority for business owners rather than assuming that the technology by itself will solve all problems (Robertson et al., 2007). Policy-makers need to ensure that where Web based approaches are adopted sufficient support is provided before and after the adoption to avoid the Web becoming a further drain on resources (OCED, 2010; Chaplin and Booth di Giovanni, 2010).

\section{Conclusions}

The results of the paper find that those firms using their Websites for more activities are more likely to be innovative. However, those firms with active Websites are not only more likely to innovate and grow, but are also more likely to fall into the innovative but low growth group. This means that the presence of an active Website may increase the probability of innovative activities, but has less influence in ensuring that this innovation leads to growth as well. From a policy perspective one possible explanation for the lack of benefit from the Internet in helping both innovation and growth to be achieved by UK SMEs simultaneously could be the lack of IT skills present in most SMEs (Weltevreden and Boschma, 2008; Thompson et al., 2010). This lack of proficiency could result in the Internet being more of a distraction than a benefit. Given the investments being made in digital infrastructure it might be that further investment needs to be made in complementary training to allow SMEs to utilise this digital technology to its fullest extent, but this requires further analysis.

The results can only highlight the relationships between Website usage and the outcomes achieved by UK SMEs. The reasons for these relationships might be predicted from the existing literature, but given the lack of consensus in terms of the net benefits associated with Web adoption (Coad, 2007; Coad and Rao, 2008; Jehangir et al., 2011), further study is encouraged to examine these issues further. However, for small business owners the results highlight the danger in assuming that new technologies will provide their businesses with a competitive edge automatically. Owners need to ensure that business strategies fully incorporate new technologies with a clear understanding of what the consequences are of adopting these technologies. Future qualitative work could provide considerable value in examining how more innovative SMEs attempt to use the Internet within their businesses and through comparisons with those taking alternative routes, identify where benefits and costs arise in terms of releasing (or swallowing) resources for innovative activities, or directly acting as an input into the innovation process. Quantitative work with a greater longitudinal element would also be of value given that where a relationship between innovation and performance is suggested to exist, this can vary with the time frame utilised (Freel and Robson, 2004).

This paper has found that for UK SMEs there is little evidence that development of an active Website allows firms to both take an innovative approach and grow. Given the attention and promotion that the Internet enjoys as a solution to many problems these results at the very least should suggest that further work must be undertaken to establish whether SMEs should be encouraged to make such investments and if so what additional help is required to ensure that investments in this digital infrastructure achieves a return appropriate for the investment. 


\section{References}

Acs, Z.J. and Armington, C. (2004), "Employment growth and entrepreneurial activity in cities", Regional Studies, Vol. 38 No. 8, pp. 911-927.

Acs, Z.J., Anselin, L. and Varga, A. (2002), "Patents and innovation counts as measures of regional production of new knowledge", Research Policy, Vol. 31 No. 7, pp. 1069-1085.

Acs, Z.J. and Audretsch, D.B. (1989), "Patents as a measure of innovative activity", Kyklos, Vol. 42 No. 2, pp. 171-180.

Amit, R. and Schoemaker, P.J.H. (1993), "Strategic assets and organizational rent", Strategic Management Journal, Vol. 14 No. 1, 33-46.

Audretsch, D.B. (2004), "Sustaining innovation and growth: public policy support for entrepreneurship", Industry and Innovation, Vol. 11 No. 3, pp. 167-191.

Audretsch, D.B. and Keilbach, M. (2004), "Entrepreneurship and regional growth: an evolutionary interpretation", Journal of Evolutionary Economics, Vol. 14 No. 5, pp. 605-616.

Beijerse, R. P. uit (2000), "Knowledge management in small and medium-sized companies: knowledge management for entrepreneurs", Journal of Knowledge Management, Vol. 4 No. 2, pp. 162-179.

Bergemann, D. (2005), "The financing of innovation: learning and stopping", RAND Journal of Economics, Vol. 36 No. 4, pp. 719-752.

Bewley, H., Forth, J. and Robinson, C. (2010), Evaluation methodology: measurement of drivers of business success and failure, Department of Business Innovation and Skills (BIS), London.

Beynon-Davies, P. (2010), "eBusiness as a driver for regional development", Journal of Systems and Information Technology, Vol. 12 No. 1, pp. 17-36.

Bilbao-Osorio, B. and Rodríguez-Pose, A. (2004), "From R\&D to innovation and economic growth in the EU", Growth and Change, Vol. 35 No. 4, pp. 434-455.

Birch, D. (1987), Job Generation in America: How our Smallest Companies Put the Most People to Work, Free Press, New York, NY.

Black, G. (2004), The Geography of Small Firm Innovation, Kluwer, Norwell, MA.

Blackburn, R., Kitching, J., Hart, M., Brush, C. and Ceru, D. (2008), Growth Challenges for Small and Medium-sized Enterprises: A UK-US Comparative Study, Small Business Research Centre, Kingston University, Kingston upon Thames. 
Blundell, R., Dearden, L., Meghir, C. and Sianesi, B. (1999), "Human capital investment: the returns from education and training to the individual, the firm and the economy", Fiscal Studies, Vol. 20 No. 1, pp. 1-23.

Bosma, N., van Praag, M., Thurik, R. and de Wit, G. (2004), "The value of human and social capital investments for the business performance of startups", Small Business Economics, Vol. 23 No. 3, 227-236.

Bougrain, F. and Haudeville, B. (2002), "Innovation, collaboration and SMEs internal research capacities", Research Policy, Vol. 31 No. 5, pp. 735-747.

Carter, N.M., Gartner, W.B., Shaver, K.G. and Gatewood, E.J. (2003), "The career reasons of nascent entrepreneurs", Journal of Business Venturing, Vol. 18 No. 1, pp. 13-39.

Cefis, E. and Marsili, O. (2006), "Survivor: the role of innovation in firm's survival", Research Policy, Vol. 35 No. 5, pp. 626-641.

Chaplin, H. and Booth di Giovanni, H. (2010), "Internationalisation of innovative and high growth SMEs", Department for Business Innovation and Skills Economics Paper No. 5.

Christensen, C.M. (1997), The innovator's dilemma: When new technologies cause great firms to fail, Harvard Business School Press, Boston, MA.

Christensen, C.M. and Raynor, M.E. (2003), The innovator's solution: Creating and sustaining successful growth, Harvard Business School Press, Boston, MA.

Clifton, N., Keast, R., Pickernell, D. and Senior, M. (2010), "Network structure, knowledge governance, and firm performance: evidence from innovation networks and SMEs in the UK", Growth and Change, Vol. 41 No. 3, pp. 337-373.

Coad, A. (2007), Firm Growth: A Survey. Papers on Economics \& Evolution. Max Planck Institute of Economics, Jena, Germany. May 14, pp. 1-72.

Coad, A. and Rao, R. (2008), "Innovation and firm growth in high-tech sectors: a quantile regression approach", Research Policy, Vol. 37 No. 4, pp. 633-648.

Cohen, J., Cohen, P., West, S.G. and Aiken, L.S. (2003), Applied multiple regression/correlation analysis for the behavioral sciences: third edition. Lawrence Erlbaum Associates, Mahwah, NJ.

Cohen, S. and Kallirroi, G. (2006), "e-commerce investments from a SME perspective: costs, benefits and processes", Electronic Journal of Information Evaluation, Vol. 9 No. 2, pp. 45-56.

Colombo, M.G. and Grilli, L. (2005), "Founders' human capital and the growth of new technology-based firms: a competence-based view", Research Policy, Vol. 34 No. 6, pp. 795-816. 
Cooke, P. Clifton, N. and Oleaga, M. (2005), "Social capital, firm embeddedness and regional development”, Regional Studies, Vol. 39 No. 8, pp. 1065-1077.

Cooper, A.C., Gimeno-Gascon, F.J. and Woo, C.Y. (1994), "Initial human capital and financial capital as predictors of new venture performance", Journal of Business Venturing, Vol. 9 No. 5, 371-396.

Cosh, A.D., Hughes, A. and Wood, E. (1999), "Innovation in UK SMEs: causes and consequences for firm failure and acquisition", in Acs, Z.J. and Carlsson, B. (Eds.) Entrepreneurship, Small and Medium Sized Enterprises and the Macro Economy, Cambridge University Press, Cambridge, pp. 329-366.

Davidsson, P., Steffens, P. and Fitzsimmons, J. (2009), "Growing profitable or growing from profits: putting the horse in front of the cart?", Journal of Business Venturing, Vol. 24 No. 4, pp. 388-406.

Davis, S.J., Haltiwanger, J. and Schuh, S. (1996), "Small business and job creation: dissecting the myth and reassessing the facts", Small Business Economics, Vol. 8 No. 4, pp. 297-315.

Department for Trade and Industry (DTI) (2006), "International trade and investment - the economic rationale for government support", DTI Economics Paper No. 18, Department for Trade and Industry, London, July.

Dibrell, C., Davis, P.S. and Craig. J. (2008), "Fueling innovation through information technology in SMEs", Journal of Small Business Management, Vol. 46, No. 2, pp. 203-218.

Dutta, S. and Evrard, P. (1999), "Information technology and organisation within European small enterprises", European Management Journal, Vol. 17 No. 3, pp. 239-251.

Edwards, T., Delbridge, R. and Munday, M. (2001), "Linking innovative potential to SME performance: an assessment of enterprise in industrial South Wales", paper presented at the $41^{\text {st }}$ European Regional Association Meeting, 29 ${ }^{\text {th }}$ August, Zagreb, Croatia.

Engel, D., Rothgang, M. and Trettin, L. (2004), "Innovation and their impact on growth of SME - Empirical evidence from craft dominated industries in Germany", paper presented at the EARIE Conference, $2^{\text {nd }}-5^{\text {th }}$ September, Berlin, Germany.

Freel, M.S. (2000), "Do small innovating firms outperform non-innovators?", Small Business Economics, Vol. 14 No. 3, pp. 195-210.

Freel, M.S. and Robson, P. (2004), "Small firm innovation, growth and performance: Evidence from Scotland and Northern England", International Small Business Journal, Vol. 22 No. 6, 561-575.

Freeman, C. and Soete, L. (1997), The economics of industrial innovation, Routledge, Abingdon. 
Fruhling, A.L. and Siau, K. (2007), "Assessing organizational innovation capability and its effect on e-commerce initiatives", Journal of Computer Information Systems, Vol. 47 No. 4, pp. 133-145.

Garicano, L. and Kaplan, S.N. (2001), "The effects of business-to-business ecommerce on transaction costs", Journal of Industrial Economics, Vol. 49 No. 4, pp. 463-485.

Gorton, M. (1999), "Spatial variations in markets served by UK-based small and medium sized enterprises (SMEs)", Entrepreneurship and Regional Development, Vol. 11 No. 1, pp. 39-55.

Grant, R. and Baden-Fuller. C. (2004), "A knowledge accessing theory of strategic alliances", Journal of Management Studies, Vol. 41 No. 1, pp. 61-84.

Grimes, S. (2003), "The digital economy challenge facing peripheral rural areas", Progress in Human Geography, Vol. 27 No. 2, pp. 174-193.

Hadjimanolis, A. and Dickson, K. (2000), "Innovation strategies of SMEs in Cyprus, a small developing country", International Small Business Journal, Vol. 18 No. 4, pp. 62-79.

Hamill, J. (1997), "The Internet and international marketing", International Marketing Review, Vol. 14 No. 5, pp. 300-311.

Hansen, B. and Hamilton, R. T. (2011), "Factors distinguishing small firm growers and non-growers", International Small Business Journal, Vol. 29 No. 3, pp. 278-294.

Heimonen, T. (2012), "What are the factors that affect innovation in growing SMEs?", European Journal of Innovation Management, Vol. 15 No. 1, pp. 122-144.

Hewitt-Dundas, N. (2006), "Resource and capability constraints to innovation in large and small plants", Small Business Economics, Vol. 26 No. 3, pp. 257-277.

Hodges D, (2010), "Investigating the links between innovation and productivity: an analysis of UK firms", Department for Business Innovation and Skills Economics Paper, No. 15.

Hoffman, K., Parejo, M., Bessant, J. and Perren, L. (1998), "Small firms, R\&D, technology and innovation in the UK: a literature review", Technovation, Vol. 18 No. 1, pp. 39-55.

Howells, J. (2005), "Innovation and regional economic development: a matter of perspective", Research Policy, Vol. 34 No. 8, pp. 1220-1234.

Huang, Y-H. and Tsai, M-T. (2011), "A study of service innovation in Small and Medium Enterprises (SMEs): evidence from e-commerce systems", Research Journal of International Studies, Vol. 18, pp. 101-113. 
Huggins, R. and Johnston, A. (2009), "Knowledge networks in an uncompetitive region: SME innovation and growth", Growth and Change, Vol. 40 No. 2, pp. 227259.

Huggins, R., Prokop, D., Thompson, P., Brooksbank, D. and Morgan, B. (2012), Sustainable entrepreneurship in Wales: A Study of the Factors Underpinning New Venture Survival, Cardiff University, Cardiff.

Humphreys, P., McAdam, R. and Leckney, J. (2005), "Longitudinal evaluation of innovation implementation in SMEs", European Journal of Innovation Management, Vol. 8 No. 3, pp. 283-304.

Jehangir, M., Dominic P.D.D. and Downe, A. G. (2011), "Business resources impact on e-commerce capability and e-commerce value: an empirical investigation", Trends in Applied Sciences Research, Vol. 6 No. 9, pp. 1063-1070.

Johnson, A. and Drewett, A. (2011), "Examining leadership of the innovation process in SMEs'. paper presented at the Institute of Small Business and Entrepreneurship Conference, $9^{\text {th }}-10^{\text {th }}$ November, Sheffield, UK.

Judge, W.Q., Fryxell, G.E., and Dooley, R.S. (1997), "The new task of R\&D management: creating goal-directed communities for innovation", California Management Review, Vol. 39 No. 3, pp. 72-85.

Keizer, J.A., Dijkstra, L. and Halman, J.I.M. (2002), "Explaining innovative efforts of SMEs: an exploratory survey among SMEs in the mechanical and electrical engineering sector in the Netherlands", Technovation, Vol. 22 No. 1, pp. 1-13.

Khan, A.M. and Manopichetwattana, V. (1989), "Innovative and non-innovative small firms: types and characteristics", Management Science, Vol. 35 No. 5, pp. 597-606.

Kirchhoff, B.A. (1996), "Self-employment and dynamic capitalism", Journal of Labor Research, Vol.17 No. 4, pp. 627-643.

Kitching, J. and Blackburn, R. (1998), "Intellectual property management in the small and medium enterprise (SME)", Journal of Small Business and Enterprise Development, Vol. 5 No. 4, pp. 327-335.

Klecka, W.R. (1980), Discriminant Analysis: Quantitative Applications in the Social Sciences, Sage, Los Angeles, CA.

Knight, G.A. and Cavusgil, S.T. (2004), "Innovation, organizational capabilities, and the born-global firm", Journal of International Business Studies, Vol. 35 No. 2, pp. 124-141.

Koellinger, P. (2008), "Why are some entrepreneurs more innovative than others?", Small Business Economics, Vol. 31 No. 1, pp. 21-37. 
Koschatzky, K., Bross, U. and Stanovnik, P. (2001), "Development and innovation potential in the Slovene manufacturing industry: analysis of an industrial innovation survey", Technovation, Vol. 21 No. 5, pp. 311-324.

Laforet, S. and Tann, J. (2006), "Innovative characteristics of small manufacturing firms", Journal of Small Business and Enterprise Development, Vol. 13 No. 3, pp. 363-380.

Lawson, R., Alcock, C., Cooper, J. and Burgess, L. (2003). "Factors affecting adoption of electronic commerce technologies by SMEs: an Australian study", Journal of Small Business and Enterprise Development, Vol. 10 No. 3, pp. 265-276.

Lee, R. and Jones, O. (2008), "Networks, communication and learning during business start-up: the creation of cognitive social capital", International Small Business Journal, Vol. 26 No. 5, pp. 559-594.

Lee, S.G., Koo, C. and Nam, K. (2010), "Cumulative strategic capability and performance of early movers and followers in the cyber market", International. Journal. Information. Management, Vol. 30 No. 3, pp. 239-255.

Lévesque, M. and Minniti, M. (2006). "The effect of aging on entrepreneurial behaviour", Journal of Business Venturing, Vol. 21 No. 2, pp. 177-194.

Levy, M., Powell, P. and Yetton, P. (2002), "The dynamics of SME information systems", Small Business Economics, Vol. 19 No. 4, pp. 341-354.

Loof H. and Heshmatt A. (2006), "On the relationship between innovation and performance: a sensitivity analysis", Economics of Innovation and New Technologies Vol.15 No. 4/5, pp. 317-344.

Macpherson, A. and Holt, R. (2007), "Knowledge, learning and small firm growth: A systematic review of the evidence", Research Policy, Vol. 36 No. 2, pp. 172-192.

Macpherson, A. and Holt, R. (2007), "Knowledge, learning and small firm growth: a systematic review of the evidence", Research Policy, Vol. 36 No. 2, pp.172-192.

Macredie, R.D. and Mijinyawa, K. (2011), "A theory-grounded framework of Open Source Software adoption in SMEs", European Journal of Information Systems, Vol. 20 No. 2, pp. 237-250.

Marvel, M.R. and Lumpkin, G.T. (2007), "Technology entrepreneurs' human capital and its effects on innovation radicalness", Entrepreneurship Theory and Practice, Vol. 31 No. 6, pp. 807-828.

Mathews, S.W. and Healy, M.J. (2007), "The Internet and information capability reduces perceived risk of internationalisation: an Australian SME perspective", International Journal of Organisation Behaviour, Vol. 12 No. 1, pp. 71-87.

McAdam, R., McConvery, T. and Armstrong, G. (2004), "Barriers to innovation within small firms in a peripheral location", International Journal of Entrepreneurial Behaviour and Research, Vol. 10 No. 3, pp. 206-221. 
McAdam, R., Moffett, S., Hazlett, S.A. and Shevlin, M. (2010), "Developing a model of innovation implementation for UK SMEs: A path analysis and explanatory case analysis", International Small Business Journal, Vol. 28 No. 3, pp. 195-214.

Narula, R. (2003), Globalisation and Technology, Polity Press: Cambridge

Napier, H.A., Judd, P.J., Rivers, O.N. and Wagner, S.W. (2001), Creating a Winning E-Business, Course Technology, Boston, MA.

Nooteboom, B. (1994), "Innovation And diffusion in small firms: theory and evidence", Small Business Economics, Vol. 6 No. 5, pp. 327-347.

North, D., Leigh, R. and Smallbone, D.J. (1992), "A comparison of surviving and nonsurviving small and medium sized manufacturing firms in London during the 1980s", in Caley, K., Chell, E., Chittenden, F., and Mason, C. (Eds.), Small Enterprise Development: Policy and Practice in Action, Paul Chapman Publishing, London, pp. 12-27.

North, D. and Smallbone, D. (2000), "The innovativeness and growth of rural SMEs during the 1990s", Regional Studies. Vol. 34, No. 2, pp. 145-157.

OECD (2010), OECD Reviews of Innovation Policy: Synthesis of Country Reports, Paris, Organisation for Economic Co-operation and Development.

Ordanini, A. and Rubera, G. (2010), "How does the application of an IT service innovation affect firm performance: a theoretical framework and empirical analysis on e-commerce", Information and Management., Vol.47 No. 1, pp. 60-67.

Packham, G. (2002), "Competitive advantage and growth: the challenge for small firms", International Journal of Management and Decision-Making, Vol. 3 No. 2, pp. 165-179.

Packham, G., Brooksbank, D., Miller, C. and Thomas, B. (2005), "Climbing the mountain: management practice adoption in growth oriented firms in Wales", Small Business and Enterprise Development, Vol. 12 No. 4, pp. 482-497.

Parker, R. (2001), "The myth of the entrepreneurial economy: employment and innovation in small firms", Work, Employment and Society, Vol. 15 No. 2, pp. 373384.

Phelps, R., Adams, R. and Bessant, J. (2007), "Life cycles of growing organizations: a review with implications for knowledge and learning", International Journal of Management Reviews, Vol. 9 No. 1, pp. 1-30.

Phillips, B.D. and Kirchhoff, B.A. (1989), "Formation, growth and survival: small firm dynamics in the US economy", Small Business Economics, Vol. 1 No. 1, pp. 65-74. 
Pickernell, D., Packham, G., Brooksbank, D. and Jones, P. (2010), "A recipe for what? UK universities, enterprise and knowledge transfer", Entrepreneurship and Innovation, Vol. 11 No. 4, pp. 265-272.

Pickernell, D. Packham, G. Jones, P. Miller, C. and Thomas, B. (2011), "Graduate entrepreneurs are different: they access more resources?", International Journal of Entrepreneurial Behaviour and Research, Vol. 17 No. 2, pp. 183-202.

Porter, M.E. (2004), Competitive Advantage, Free Press, New York, NY.

Prosser, L. (2009), UK Standard Industrial Classification of Economic Activities 2007 (SIC 2007): Structure and Explanatory Notes. Palgrave Macmillan, Basingstoke.

Roach, D.C. (2011), "The impact of product management on SME performance: Evidence from Canadian firms", Journal of Small Business and Enterprise Development, Vol. 18 No. 4, pp. 695-714.

Robertson, A., Lockett, N., Brown, D. and Crouchley, R. (2007), "Entrepreneur attitude towards the computer and its effect on e-Business adoption", paper presented at the $30^{\text {th }}$ Institute for Small Business and Entrepreneurship (ISBE) Conference, $7^{\text {th }}-9^{\text {th }}$ November, Glasgow, United Kingdom.

Robertson, P., Smith, K. and von Tunzelmann, N. (2009), "Innovation in low and medium-technology industries", Research Policy, Vol. 38 No. 3, pp. 441-446.

Romano, C.A. (1990), "Identifying factors which influence product innovation: a case study approach", Journal of Management Studies, Vol. 27 No. 1, pp. 75-95.

Romijn, H. and Albaladejo, M. (2002), "Determinants of innovation capability in small electronics and software firms in southeast England", Research Policy, Vol. 31 No. 7, pp. 1053-1067.

Roper, S. (1997), "Product innovation and small business growth: a comparison of the strategies of German, UK and Irish companies", Small Business Economics, Vol. 9 No. 6 , pp. 523-537.

Rosenbusch, N., Brinckman, J. and Bausch, A. (2011), "Is innovation always beneficial? A meta-analysis of the relationship between innovation and performance in SMEs", Journal of Business Venturing, Vol. 26 No. 4, pp. 441-457.

Smeltzer, L.R., Fann, G.L. and Nikolaisen, V.N. (1988), "Environmental scanning practices in small business", Journal of Small Business Management, Vol. 26 No. 3, pp. 55-62.

Soto-Acosta, P., Colomo-Palacios, R. and Perez-Gonzalez, D. (2011), "Examining whether highly e-innovative firms are more e-effective", Informatica, Vol. 35 No. 4, pp. $481-488$

Souitaris, V. (2001), "Strategic influences of technological innovation in Greece", British Journal of Management, Vol. 12 No. 2, pp. 131-147. 
St-Jean, E., Julien, J-R. and Audet, J. (2008), "Factors associated with growth changes in "gazelles"', Journal of Enterprising Culture, Vol. 16 No. 2, pp. 161-188.

Storey, D.J. (1994), Understanding the Small Business Sector, Routledge, London.

Teece, D. (1998), "Capturing value from knowledge assets: The new economy, markets for know-how, and intangible assets", California Management Review, Vol. 40 No. 3, pp. 55-79.

Thompson, P., Brooksbank, D., Jones-Evans, D. and Kwong, C. (2007), "Who are the innovative entrepreneurs?", paper presented at the International Society for Professional Innovation Management Conference, $17^{\text {th }}-20^{\text {th }}$ June, Warsaw, Poland.

Thompson, P., Williams, R., Thomas, B. C. and Packham, G. (2010), "Shortages of IT skills in UK SMEs", paper presented at the $33^{\text {rd }}$ Institute for Small Business and Enterprise Conference, $3^{\text {rd }}-4^{\text {th }}$ November, London, UK.

Thorpe, R., Holt, R., Macpherson, A. and Pittaway, L. (2005), "Using knowledge within small and medium-sized firms: a systematic review of the evidence", International Journal of Management Review, Vol. 7 No. 4, pp. 257-281.

Tiwari, R. and Buse, S. (2007), "Barriers to innovation in SMEs: can the internationalization of R\&D mitigate their effects?", paper presented at the First European Conference on Knowledge for Growth: Role and Dynamics of Corporate R\&D, $8^{\text {th }}-9^{\text {th }}$ October, Seville, Spain.

Verhees, F.H.M. and Meulenberg, M.T.G. (2004), "Market orientation, innovativeness, product innovation, and performance in small firms", Journal of Small Business Management, Vol. 42 No. 2, pp. 134-154.

Weltevreden, J.W.J. and Boschma, R.A. (2008), "The influence of firm owner characteristics on Internet adoption by independent retailers: a business survey", International Journal of Internet Science, Vol. 3 No. 1, pp. 34-54.

Wennekers, S. and Thurik, R. (1999), "Linking entrepreneurship and economic growth", Small Business Economics, Vol. 13 No. 1, pp. 27-55.

Wennekers, S., van Stel, A., Thurik, R. and Reynolds, P. (2005), "Nascent entrepreneurship and the level of economic development", Small Business Economics, Vol. 24 No. 3, pp. 293-309.

Wigand, R. (1997), "Electronic commerce: definition, theory, and context", Information Society, Vol. 13 No. 1, pp. 1-16.

Williams, R., Packham, G. P., Thomas, B. C. and Thompson, P. (2010), "Small business sales growth and internationalization links to website functions in the United Kingdom", in Thomas, B. C. and Simmons, G. (Eds.), E-Commerce Adoption and Small Business in the Global Marketplace: Tools for Optimization, IGI Global: Hershey PA, pp. 139-173.. 
Wu, J-H. and Hisa, T-L. (2004), "Analysis of E-commerce innovation and impact: a hypercube model", Electronic Commerce Research and Applications, Vol. 3 No. 4, pp. 389-404.

Wu, J-H. and Hisa, T-L. (2008), "Developing Ebusiness dynamic capabilities: an analysis of Ecommerce innovation from I-, M-, to U-commerce", Journal of Organizational Computing and Electronic Commerce, Vol. 18 No. 2, pp. 95-111.

Yli-Renko, H. and Autio, E. (1998), "The network embeddedness of new technologybased firms: developing a systematic evolution model", Small Business Economics, Vol. 11 No. 6/7, pp. 253-267.

Yli-Renko, H., Autio, E. and Sapienza, H.J. (2001), "Social capital, knowledge acquisition, and knowledge exploitation in young technology-based firms", Strategic Management Journal, Vol. 22 No. 6/7, pp. 587-613.

Zhu, K. and Kraemer, K.L. (2002), "E-commerce metrics for Net-enhanced organizations: assessing the value of e-commerce to firm performance in the manufacturing sector", Information Systems Research, Vol. 13 No. 3, pp. 275-295.

Zhu, K., Xu, S. and Kraemer, K.L. (2006), "The global diffusion and convergence of E-commerce: cross-country analyses", in Kraemer, K.L., Dedrick, J., Melville, N.P., and Zhu, K. (Eds.), Global E-Commerce: Impacts of National Environment and Policy, Cambridge University Press, Cambridge, pp. 345-384.

Zucchella, A. (2009), "Barriers to internationalisation of SMEs: an analysis from the perspective of support service providers". paper presented at the annual AIBUK and Ireland Chapter Conference, $2^{\text {nd- }} 4^{\text {th }}$ April, Glasgow, UK.. 
Figure 1 - Categorisation of businesses by growth and innovative orientation over the previous two years

\begin{tabular}{|c|c|c|}
\hline & No Innovation Orientation & Innovation Orientation \\
\hline No Growth & $\begin{array}{l}\text { Low Growth non- } \\
\text { innovatively orientated } \\
\text { businesses }\end{array}$ & $\begin{array}{l}\text { Low Growth innovatively } \\
\text { orientated businesses }\end{array}$ \\
\hline Growth & $\begin{array}{l}\text { Growing non-innovatively } \\
\text { orientated businesses }\end{array}$ & $\begin{array}{l}\text { Growing innovatively } \\
\text { orientated businesses }\end{array}$ \\
\hline
\end{tabular}

Table 1 - Proportion of firms achieving growth and establishing an innovative orientation

\begin{tabular}{ccc}
\hline & $\begin{array}{c}\text { Sample based on } \\
\text { Website Utilisation }\end{array}$ & $\begin{array}{c}\text { Sample based on e- } \\
\text { commerce sales }\end{array}$ \\
\hline High Sales Growth & $15.9 \%$ & $16.7 \%$ \\
High Profits Growth & $17.6 \%$ & $18.4 \%$ \\
Innovative Orientation & $8.7 \%$ & $9.2 \%$ \\
$N$ & 5982 & 4786 \\
\hline $\begin{array}{l}\text { Notes: High sales growth defined as 20\% or more in the past 2 years; High profits } \\
\text { growth defined as 10\% or more in the last 2 years; Innovation orientation is defined }\end{array}$ \\
as rating the importance of increasing R\&D spending as 4 or 5 out of 5.
\end{tabular}

Table 2 - Pearson correlation coefficients of performance and innovation orientation measures

\begin{tabular}{|c|c|c|}
\hline & Sales Growth & Profits Growth \\
\hline Profits Growth & $\begin{array}{c}0.465 \\
(0.000)\end{array}$ & \\
\hline Innovative Orientation & $\begin{array}{c}0.097 \\
(0.000)\end{array}$ & $\begin{array}{c}0.056 \\
(0.000)\end{array}$ \\
\hline
\end{tabular}


Table 3 - Mulitnominal logit regression for Four Categories of SMEs, Website usage measured directly

\begin{tabular}{|c|c|c|c|c|c|c|}
\hline & \multicolumn{3}{|c|}{ Growth Measured by Profits } & \multicolumn{3}{|c|}{ Growth Measured by Sales } \\
\hline & 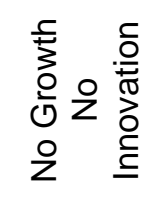 & 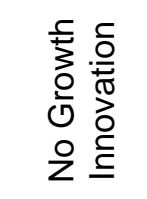 & 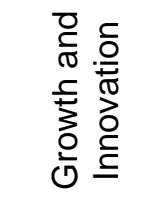 & 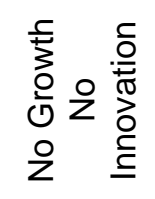 & 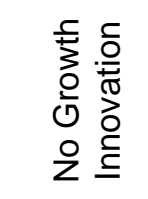 & 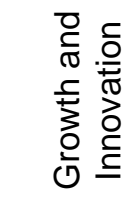 \\
\hline \multicolumn{7}{|l|}{$\begin{array}{l}\text { Website (b.c. non- } \\
\text { interactive website) }\end{array}$} \\
\hline No Website & $\begin{array}{l}\mathbf{0 . 2 0 1 4} \\
(0.040)\end{array}$ & $\begin{array}{l}-0.5005 \\
(0.008)\end{array}$ & $\begin{array}{l}-1.0604 \\
(0.010)\end{array}$ & $\begin{array}{l}\mathbf{0 . 3 2 1 6} \\
(0.004)\end{array}$ & $\begin{array}{l}-0.3237 \\
(0.097)\end{array}$ & $\begin{array}{r}-1.3774 \\
(0.004)\end{array}$ \\
\hline Interactive Website & $\begin{array}{l}-0.0531 \\
(0.616)\end{array}$ & $\begin{array}{l}\mathbf{0 . 4 8 3 4} \\
(0.002)\end{array}$ & $\begin{array}{l}\mathbf{0 . 4 7 8 2} \\
(0.041)\end{array}$ & $\begin{array}{l}-0.3053 \\
(0.005)\end{array}$ & $\begin{array}{l}0.2194 \\
(0.170)\end{array}$ & $\begin{array}{l}\mathbf{0 . 4 4 5 4} \\
(0.039)\end{array}$ \\
\hline \multicolumn{7}{|l|}{$\begin{array}{l}\text { Turnover } \\
\text { (b.c. } £ 100,000 \text { - } \\
£ 500,000)\end{array}$} \\
\hline Less than $£ 100,000$ & $\begin{array}{l}\mathbf{0 . 3 2 4 8} \\
(0.000)\end{array}$ & $\begin{array}{l}-0.0241 \\
(0.873)\end{array}$ & $\begin{array}{l}-0.5118 \\
(0.047)\end{array}$ & $\begin{array}{l}\mathbf{0 . 3 2 4 1} \\
(0.001)\end{array}$ & $\begin{array}{l}-0.0953 \\
(0.548)\end{array}$ & $\begin{array}{l}-0.2220 \\
(0.339)\end{array}$ \\
\hline More than $£ 500,000$ & $\begin{array}{l}-0.4249 \\
(0.000)\end{array}$ & $\begin{array}{l}-0.0942 \\
(0.571)\end{array}$ & $\begin{array}{l}-0.0072 \\
(0.976)\end{array}$ & $\begin{array}{l}-0.4696 \\
(0.000)\end{array}$ & $\begin{array}{l}-0.1614 \\
(0.353)\end{array}$ & $\begin{array}{l}0.0038 \\
(0.987)\end{array}$ \\
\hline \multicolumn{7}{|l|}{$\begin{array}{c}\text { Firm age (b.c. } 4 \text { to } 9 \\
\text { years) }\end{array}$} \\
\hline Less than 4 years & $\begin{array}{l}-0.6966 \\
(0.000)\end{array}$ & $\begin{array}{l}-0.2512 \\
(0.139)\end{array}$ & $\begin{array}{l}-0.6810 \\
(0.016)\end{array}$ & $\begin{array}{l}-1.0805 \\
(0.000)\end{array}$ & $\begin{array}{l}-0.5766 \\
(0.001)\end{array}$ & $\begin{array}{l}-0.6535 \\
(0.004)\end{array}$ \\
\hline 10 to 19 years & $\begin{array}{l}0.2292 \\
(0.027)\end{array}$ & $\begin{array}{l}0.1652 \\
(0.322)\end{array}$ & $\begin{array}{l}-0.3311 \\
(0.193)\end{array}$ & $\begin{array}{l}\mathbf{0 . 8 0 6 8} \\
(0.000)\end{array}$ & $\begin{array}{l}\mathbf{0 . 8 5 5 8} \\
(0.000)\end{array}$ & $\begin{array}{l}-0.4274 \\
(0.136)\end{array}$ \\
\hline 20 years or more & $\begin{array}{l}0.3827 \\
(0.003)\end{array}$ & $\begin{array}{l}0.0231 \\
(0.914)\end{array}$ & $\begin{array}{l}-0.4665 \\
(0.169)\end{array}$ & $\begin{array}{l}1.1216 \\
(0.000)\end{array}$ & $\begin{array}{l}\mathbf{0 . 8 3 3 3} \\
(0.000)\end{array}$ & $\begin{array}{l}-0.2919 \\
(0.458)\end{array}$ \\
\hline Urban Location & $\begin{array}{l}-0.0953 \\
(0.243)\end{array}$ & $\begin{array}{l}-0.1230 \\
(0.351)\end{array}$ & $\begin{array}{l}-0.4108 \\
(0.044)\end{array}$ & $\begin{array}{l}0.0697 \\
(0.425)\end{array}$ & $\begin{array}{l}-0.0693 \\
(0.611)\end{array}$ & $\begin{array}{l}-0.0235 \\
(0.906)\end{array}$ \\
\hline \multicolumn{7}{|l|}{ Industry (b.c. retail) } \\
\hline $\begin{array}{l}\text { Agriculture and } \\
\text { extractive }\end{array}$ & $\begin{array}{l}-0.5782 \\
(0.000)\end{array}$ & $\begin{array}{l}-0.0624 \\
(0.801)\end{array}$ & $\begin{array}{l}1.0849 \\
(0.015)\end{array}$ & $\begin{array}{l}-0.4945 \\
(0.001)\end{array}$ & $\begin{array}{l}0.1489 \\
(0.559)\end{array}$ & $\begin{array}{l}0.6161 \\
(0.118)\end{array}$ \\
\hline Manufacturing & $\begin{array}{l}-0.5450 \\
(0.000)\end{array}$ & $\begin{array}{l}0.4176 \\
(0.085)\end{array}$ & $\begin{array}{l}1.7630 \\
(0.000)\end{array}$ & $\begin{array}{l}-0.3802 \\
(0.027)\end{array}$ & $\begin{array}{l}\mathbf{0 . 7 8 9 7} \\
(0.002)\end{array}$ & $\begin{array}{l}1.1812 \\
(0.002)\end{array}$ \\
\hline Transport, and Utilities & $\begin{array}{l}-0.3889 \\
(0.037)\end{array}$ & $\begin{array}{l}0.2626 \\
(0.380)\end{array}$ & $\begin{array}{l}0.7229 \\
(0.206)\end{array}$ & $\begin{array}{l}-0.1933 \\
(0.340)\end{array}$ & $\begin{array}{l}0.3142 \\
(0.338)\end{array}$ & $\begin{array}{l}1.0177 \\
(0.024)\end{array}$ \\
\hline $\begin{array}{l}\text { Hotels and } \\
\text { Restaurants }\end{array}$ & $\begin{array}{l}0.2145 \\
(0.308)\end{array}$ & $\begin{array}{l}\mathbf{0 . 6 7 3 1} \\
(0.035)\end{array}$ & $\begin{array}{l}0.4303 \\
(0.545)\end{array}$ & $\begin{array}{l}0.3473 \\
(0.102)\end{array}$ & $\begin{array}{l}\mathbf{0 . 7 9 2 7} \\
(0.017)\end{array}$ & $\begin{array}{l}0.6421 \\
(0.228)\end{array}$ \\
\hline $\begin{array}{c}\text { Financial and real } \\
\text { estate }\end{array}$ & $\begin{array}{l}-1.0102 \\
(0.000)\end{array}$ & $\begin{array}{l}-1.2926 \\
(0.002)\end{array}$ & $\begin{array}{l}-0.0065 \\
(0.992)\end{array}$ & $\begin{array}{l}-0.6255 \\
(0.001)\end{array}$ & $\begin{array}{l}-0.7898 \\
(0.052)\end{array}$ & $\begin{array}{l}-0.4805 \\
(0.470)\end{array}$ \\
\hline Business services & $\begin{array}{l}-0.7939 \\
(0.000)\end{array}$ & $\begin{array}{l}0.2043 \\
(0.339)\end{array}$ & $\begin{array}{l}0.9879 \\
(0.019)\end{array}$ & $\begin{array}{l}-0.7784 \\
(0.000)\end{array}$ & $\begin{array}{l}0.2711 \\
(0.226)\end{array}$ & $\begin{array}{l}0.6491 \\
(0.058)\end{array}$ \\
\hline $\begin{array}{l}\text { Health, education } \\
\text { social }\end{array}$ & $\begin{array}{l}-0.8393 \\
(0.000)\end{array}$ & $\begin{array}{l}0.0371 \\
(0.897)\end{array}$ & $\begin{array}{l}-0.2600 \\
(0.712)\end{array}$ & $\begin{array}{l}-0.2277 \\
(0.255)\end{array}$ & $\begin{array}{l}0.4923 \\
(0.121)\end{array}$ & $\begin{array}{l}0.5625 \\
(0.269)\end{array}$ \\
\hline
\end{tabular}


Table 3 - continued

\begin{tabular}{|c|c|c|c|c|c|c|}
\hline & \multicolumn{3}{|c|}{ Growth measured by Profits } & \multicolumn{3}{|c|}{ Growth measured by Sales } \\
\hline & 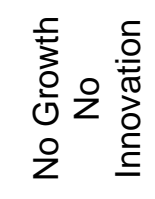 & 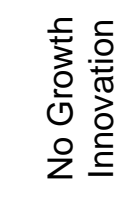 & 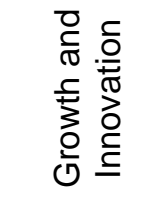 & 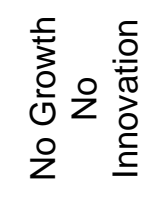 & 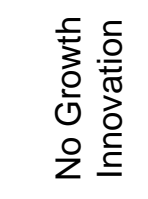 & 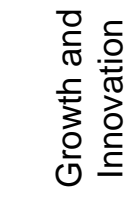 \\
\hline Consumer services & $\begin{array}{l}-0.3408 \\
(0.093)\end{array}$ & $\begin{array}{l}0.1989 \\
(0.548)\end{array}$ & $\begin{array}{l}-0.0491 \\
(0.952)\end{array}$ & $\begin{array}{l}-0.5260 \\
(0.008)\end{array}$ & $\begin{array}{l}0.1938 \\
(0.558)\end{array}$ & $\begin{array}{l}-0.8154 \\
(0.297)\end{array}$ \\
\hline Others & $\begin{array}{l}-1.0573 \\
(0.000)\end{array}$ & $\begin{array}{l}-0.1523 \\
(0.669)\end{array}$ & $\begin{array}{l}0.1549 \\
(0.827)\end{array}$ & $\begin{array}{l}-0.7866 \\
(0.001)\end{array}$ & $\begin{array}{l}-0.2053 \\
(0.616)\end{array}$ & $\begin{array}{l}0.8093 \\
(0.117)\end{array}$ \\
\hline \multicolumn{7}{|l|}{$\begin{array}{c}\text { Gender of owners (b.c. } \\
\text { equal) }\end{array}$} \\
\hline Majority male & $\begin{array}{l}-0.1044 \\
(0.227)\end{array}$ & $\begin{array}{l}-0.0351 \\
(0.804)\end{array}$ & $\begin{array}{l}0.0251 \\
(0.908)\end{array}$ & $\begin{array}{l}-0.0141 \\
(0.881)\end{array}$ & $\begin{array}{l}0.0162 \\
(0.912)\end{array}$ & $\begin{array}{l}0.1347 \\
(0.523)\end{array}$ \\
\hline Majority female & $\begin{array}{l}0.1686 \\
(0.185)\end{array}$ & $\begin{array}{l}0.1942 \\
(0.345)\end{array}$ & $\begin{array}{l}-0.2807 \\
(0.482)\end{array}$ & $\begin{array}{l}0.0846 \\
(0.517)\end{array}$ & $\begin{array}{l}0.1781 \\
(0.401)\end{array}$ & $\begin{array}{l}-0.3622 \\
(0.295)\end{array}$ \\
\hline \multicolumn{7}{|l|}{$\begin{array}{l}\text { Education (b.c. } \\
\text { GCSE/vocational) }\end{array}$} \\
\hline Postgraduate & $\begin{array}{l}-0.4693 \\
(0.001)\end{array}$ & $\begin{array}{l}0.0738 \\
(0.743)\end{array}$ & $\begin{array}{l}1.0422 \\
(0.003)\end{array}$ & $\begin{array}{l}-0.4281 \\
(0.006)\end{array}$ & $\begin{array}{l}0.2247 \\
(0.334)\end{array}$ & $\begin{array}{l}0.6538 \\
(0.058)\end{array}$ \\
\hline Bachelor & $\begin{array}{l}-0.4178 \\
(0.000)\end{array}$ & $\begin{array}{l}-0.1269 \\
(0.520)\end{array}$ & $\begin{array}{l}0.4595 \\
(0.181)\end{array}$ & $\begin{array}{l}-0.3490 \\
(0.007)\end{array}$ & $\begin{array}{l}-0.1352 \\
(0.518)\end{array}$ & $\begin{array}{l}0.5413 \\
(0.086)\end{array}$ \\
\hline Professional & $\begin{array}{l}-0.1514 \\
(0.197)\end{array}$ & $\begin{array}{l}0.0157 \\
(0.936)\end{array}$ & $\begin{array}{l}0.0244 \\
(0.947)\end{array}$ & $\begin{array}{l}-0.1878 \\
(0.143)\end{array}$ & $\begin{array}{l}-0.0150 \\
(0.941)\end{array}$ & $\begin{array}{l}-0.0074 \\
(0.983)\end{array}$ \\
\hline A-levels & $\begin{array}{l}-0.1069 \\
(0.448)\end{array}$ & $\begin{array}{l}-0.3760 \\
(0.137)\end{array}$ & $\begin{array}{l}0.5048 \\
(0.199)\end{array}$ & $\begin{array}{l}-0.1602 \\
(0.289)\end{array}$ & $\begin{array}{l}-0.4244 \\
(0.108)\end{array}$ & $\begin{array}{l}0.3458 \\
(0.349)\end{array}$ \\
\hline No Formal & $\begin{array}{l}0.2029 \\
(0.348)\end{array}$ & $\begin{array}{l}\mathbf{0 . 6 7 6 1} \\
(0.029)\end{array}$ & $\begin{array}{l}0.8751 \\
(0.091)\end{array}$ & $\begin{array}{l}0.0068 \\
(0.977)\end{array}$ & $\begin{array}{l}\mathbf{0 . 6 2 2 6} \\
(0.048)\end{array}$ & $\begin{array}{l}-0.1370 \\
(0.838)\end{array}$ \\
\hline \multicolumn{7}{|l|}{ Owner's Age } \\
\hline Age (centred) & $\begin{array}{l}0.0076 \\
(0.085)\end{array}$ & $\begin{array}{l}0.0043 \\
(0.533)\end{array}$ & $\begin{array}{l}-0.0019 \\
(0.858)\end{array}$ & $\begin{array}{l}0.0074 \\
(0.116)\end{array}$ & $\begin{array}{l}0.0086 \\
(0.236)\end{array}$ & $\begin{array}{l}-0.0101 \\
(0.349)\end{array}$ \\
\hline Age (centred) squared & $\begin{array}{l}0.0000 \\
(0.948)\end{array}$ & $\begin{array}{l}0.0003 \\
(0.485)\end{array}$ & $\begin{array}{l}0.0009 \\
(0.122)\end{array}$ & $\begin{array}{l}-0.0002 \\
(0.533)\end{array}$ & $\begin{array}{l}0.0001 \\
(0.834)\end{array}$ & $\begin{array}{l}0.0006 \\
(0.328)\end{array}$ \\
\hline Constant & $\begin{array}{l}2.3382 \\
(0.000)\end{array}$ & $\begin{array}{r}-0.8510 \\
(0.002)\end{array}$ & $\begin{array}{l}-2.6024 \\
(0.000)\end{array}$ & $\begin{array}{l}2.1999 \\
(0.000)\end{array}$ & $\begin{array}{l}-1.0474 \\
(0.000)\end{array}$ & $\begin{array}{l}-2.3123 \\
(0.000)\end{array}$ \\
\hline$N$ & 5660 & & & 5660 & & \\
\hline $\begin{array}{c}\text { LR-test (Null of } \\
\text { constant probability) }\end{array}$ & 574.9 & [78] & $(0.000)$ & 815.2 & [78] & $(0.000)$ \\
\hline$R^{2}$ & 0.067 & & & 0.099 & & \\
\hline $\begin{array}{l}\text { LR-test (Website } \\
\text { variables) }\end{array}$ & 68.0 & [6] & $(0.000)$ & 90.9 & [6] & $(0.000)$ \\
\hline
\end{tabular}

Notes: p-values in parentheses 
Table 4 - Mulitnominal logit regression for Four Categories of SMEs, Website usage measured indirectly by e-commerce sales

\begin{tabular}{|c|c|c|c|c|c|c|}
\hline & \multicolumn{3}{|c|}{ Growth Measured by Profits } & \multicolumn{3}{|c|}{ Growth Measured by Sales } \\
\hline & 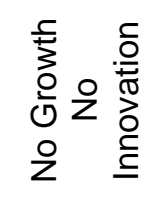 & 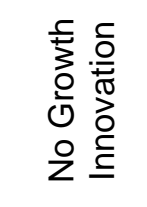 & 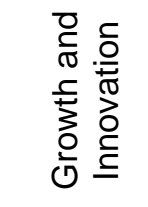 & 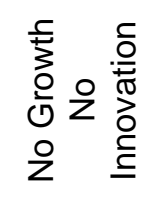 & 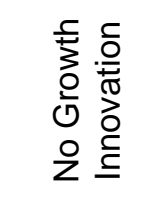 & 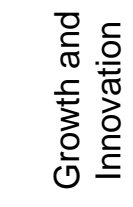 \\
\hline \multicolumn{7}{|l|}{$\begin{array}{l}\text { E-commerce sales } \\
\text { (b.c. } 1-10 \% \text { sales) }\end{array}$} \\
\hline None & $\begin{array}{l}-0.0836 \\
(0.451)\end{array}$ & $\begin{array}{l}-0.5902 \\
(0.001)\end{array}$ & $\begin{array}{l}0.1029 \\
(0.730)\end{array}$ & $\begin{array}{l}-0.1371 \\
(0.258)\end{array}$ & $\begin{array}{l}-0.6167 \\
(0.001)\end{array}$ & $\begin{array}{l}-0.0557 \\
(0.847)\end{array}$ \\
\hline More than $10 \%$ & $\begin{array}{l}-0.2624 \\
(0.053)\end{array}$ & $\begin{array}{l}0.1476 \\
(0.456)\end{array}$ & $\begin{array}{l}0.5737 \\
(0.088)\end{array}$ & $\begin{array}{l}-0.3231 \\
(0.027)\end{array}$ & $\begin{array}{l}0.0364 \\
(0.862)\end{array}$ & $\begin{array}{l}\mathbf{0 . 6 3 4 6} \\
(0.045)\end{array}$ \\
\hline \multicolumn{7}{|l|}{$\begin{array}{l}\text { Turnover } \\
\text { (b.c. } £ 100,000 \text { - } \\
£ 500,000)\end{array}$} \\
\hline Less than $£ 100,000$ & $\begin{array}{l}\mathbf{0 . 3 6 2 6} \\
(0.000)\end{array}$ & $\begin{array}{l}-0.0836 \\
(0.611)\end{array}$ & $\begin{array}{l}-0.5486 \\
(0.042)\end{array}$ & $\begin{array}{l}\mathbf{0 . 3 8 8 1} \\
(0.000)\end{array}$ & $\begin{array}{l}-0.1027 \\
(0.552)\end{array}$ & $\begin{array}{l}-0.3220 \\
(0.193)\end{array}$ \\
\hline More than $£ 500,000$ & $\begin{array}{l}-0.4264 \\
(0.000)\end{array}$ & $\begin{array}{l}-0.0954 \\
(0.599)\end{array}$ & $\begin{array}{l}0.0464 \\
(0.855)\end{array}$ & $\begin{array}{l}-0.5018 \\
(0.000)\end{array}$ & $\begin{array}{l}-0.1941 \\
(0.307)\end{array}$ & $\begin{array}{l}0.0420 \\
(0.871)\end{array}$ \\
\hline \multicolumn{7}{|l|}{$\begin{array}{c}\text { Firm age (b.c. } 4 \text { to } 9 \\
\text { years) }\end{array}$} \\
\hline Less than 4 years & $\begin{array}{l}-0.7335 \\
(0.000)\end{array}$ & $\begin{array}{l}-0.2497 \\
(0.176)\end{array}$ & $\begin{array}{l}-0.7261 \\
(0.015)\end{array}$ & $\begin{array}{l}-1.0257 \\
(0.000)\end{array}$ & $\begin{array}{l}-0.4953 \\
(0.012)\end{array}$ & $\begin{array}{l}-0.6460 \\
(0.008)\end{array}$ \\
\hline 10 to 19 years & $\begin{array}{l}0.2633 \\
(0.020)\end{array}$ & $\begin{array}{l}0.1891 \\
(0.299)\end{array}$ & $\begin{array}{l}-0.2272 \\
(0.395)\end{array}$ & $\begin{array}{l}0.9604 \\
(0.000)\end{array}$ & $\begin{array}{l}1.0301 \\
(0.000)\end{array}$ & $\begin{array}{l}-0.2643 \\
(0.378)\end{array}$ \\
\hline 20 years or more & $\begin{array}{l}\mathbf{0 . 3 8 5 4} \\
(0.006)\end{array}$ & $\begin{array}{l}0.0347 \\
(0.883)\end{array}$ & $\begin{array}{l}-0.4650 \\
(0.208)\end{array}$ & $\begin{array}{l}1.1454 \\
(0.000)\end{array}$ & $\begin{array}{l}0.9067 \\
(0.000)\end{array}$ & $\begin{array}{l}-0.3710 \\
(0.390)\end{array}$ \\
\hline Urban Location & $\begin{array}{l}-0.0861 \\
(0.335)\end{array}$ & $\begin{array}{l}-0.0392 \\
(0.787)\end{array}$ & $\begin{array}{l}-0.2936 \\
(0.178)\end{array}$ & $\begin{array}{l}0.0141 \\
(0.883)\end{array}$ & $\begin{array}{l}-0.0564 \\
(0.707)\end{array}$ & $\begin{array}{l}0.0644 \\
(0.765)\end{array}$ \\
\hline \multicolumn{7}{|l|}{ Industry (b.c. retail) } \\
\hline $\begin{array}{l}\text { Agriculture and } \\
\text { extractive }\end{array}$ & $\begin{array}{l}-0.5450 \\
(0.000)\end{array}$ & $\begin{array}{l}-0.0704 \\
(0.796)\end{array}$ & $\begin{array}{l}0.7163 \\
(0.122)\end{array}$ & $\begin{array}{l}-0.2905 \\
(0.079)\end{array}$ & $\begin{array}{l}0.2275 \\
(0.421)\end{array}$ & $\begin{array}{l}0.6090 \\
(0.150)\end{array}$ \\
\hline Manufacturing & $\begin{array}{l}-0.5400 \\
(0.001)\end{array}$ & $\begin{array}{l}0.5084 \\
(0.054)\end{array}$ & $\begin{array}{l}1.7111 \\
(0.000)\end{array}$ & $\begin{array}{l}-0.3491 \\
(0.058)\end{array}$ & $\begin{array}{l}\mathbf{0 . 8 9 1 7} \\
(0.001)\end{array}$ & $\begin{array}{l}1.2548 \\
(0.002)\end{array}$ \\
\hline Transport, and Utilities & $\begin{array}{l}-0.5179 \\
(0.010)\end{array}$ & $\begin{array}{l}0.2979 \\
(0.350)\end{array}$ & $\begin{array}{l}0.6085 \\
(0.289)\end{array}$ & $\begin{array}{l}-0.1650 \\
(0.461)\end{array}$ & $\begin{array}{l}0.3705 \\
(0.303)\end{array}$ & $\begin{array}{l}1.2841 \\
(0.005)\end{array}$ \\
\hline $\begin{array}{l}\text { Hotels and } \\
\text { Restaurants }\end{array}$ & $\begin{array}{l}0.2127 \\
(0.365)\end{array}$ & $\begin{array}{l}0.4043 \\
(0.282)\end{array}$ & $\begin{array}{l}-0.0648 \\
(0.937)\end{array}$ & $\begin{array}{l}0.3998 \\
(0.090)\end{array}$ & $\begin{array}{l}0.6924 \\
(0.068)\end{array}$ & $\begin{array}{l}-0.3788 \\
(0.635)\end{array}$ \\
\hline $\begin{array}{l}\text { Financial and real } \\
\text { estate }\end{array}$ & $\begin{array}{l}-0.9692 \\
(0.000)\end{array}$ & $\begin{array}{l}-1.4342 \\
(0.002)\end{array}$ & $\begin{array}{l}-0.3762 \\
(0.591)\end{array}$ & $\begin{array}{l}-0.5741 \\
(0.004)\end{array}$ & $\begin{array}{l}-0.8978 \\
(0.048)\end{array}$ & $\begin{array}{l}-0.8276 \\
(0.294)\end{array}$ \\
\hline Business services & $\begin{array}{l}-0.7191 \\
(0.000)\end{array}$ & $\begin{array}{l}0.3950 \\
(0.088)\end{array}$ & $\begin{array}{l}0.9755 \\
(0.021)\end{array}$ & $\begin{array}{l}-0.6891 \\
(0.000)\end{array}$ & $\begin{array}{l}0.4491 \\
(0.062)\end{array}$ & $\begin{array}{l}\mathbf{0 . 8 0 8 4} \\
(0.026)\end{array}$ \\
\hline $\begin{array}{l}\text { Health, education } \\
\text { social }\end{array}$ & $\begin{array}{l}-0.8968 \\
(0.000)\end{array}$ & $\begin{array}{l}0.2055 \\
(0.512)\end{array}$ & $\begin{array}{l}-0.1624 \\
(0.818)\end{array}$ & $\begin{array}{l}-0.2614 \\
(0.231)\end{array}$ & $\begin{array}{l}0.6232 \\
(0.072)\end{array}$ & $\begin{array}{l}0.8050 \\
(0.125)\end{array}$ \\
\hline
\end{tabular}


Table 4 - continued

\begin{tabular}{|c|c|c|c|c|c|c|}
\hline & \multicolumn{3}{|c|}{ Growth measured by Profits } & \multicolumn{3}{|c|}{ Growth measured by Sales } \\
\hline & 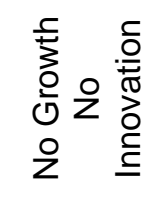 & 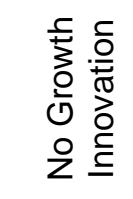 & 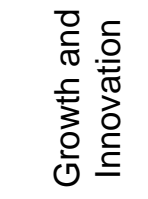 & 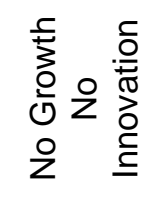 & 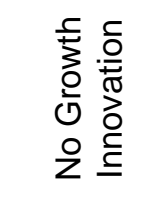 & 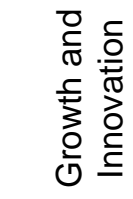 \\
\hline Consumer services & $\begin{array}{l}-0.4292 \\
(0.051)\end{array}$ & $\begin{array}{l}0.1699 \\
(0.642)\end{array}$ & $\begin{array}{l}-0.0513 \\
(0.950)\end{array}$ & $\begin{array}{l}-0.6411 \\
(0.003)\end{array}$ & $\begin{array}{l}0.1186 \\
(0.745)\end{array}$ & $\begin{array}{l}-0.6616 \\
(0.404)\end{array}$ \\
\hline Others & $\begin{array}{l}-1.0379 \\
(0.000)\end{array}$ & $\begin{array}{l}-0.1043 \\
(0.788)\end{array}$ & $\begin{array}{l}0.1905 \\
(0.789)\end{array}$ & $\begin{array}{l}-0.7498 \\
(0.003)\end{array}$ & $\begin{array}{l}-0.2378 \\
(0.600)\end{array}$ & $\begin{array}{l}0.9871 \\
(0.064)\end{array}$ \\
\hline \multicolumn{7}{|l|}{$\begin{array}{c}\text { Gender of owners (b.c. } \\
\text { equal) }\end{array}$} \\
\hline Majority male & $\begin{array}{l}-0.0666 \\
(0.481)\end{array}$ & $\begin{array}{l}-0.0512 \\
(0.737)\end{array}$ & $\begin{array}{l}-0.0628 \\
(0.782)\end{array}$ & $\begin{array}{l}0.0408 \\
(0.690)\end{array}$ & $\begin{array}{l}-0.0014 \\
(0.993)\end{array}$ & $\begin{array}{l}0.1120 \\
(0.616)\end{array}$ \\
\hline Majority female & $\begin{array}{l}0.1998 \\
(0.156)\end{array}$ & $\begin{array}{l}-0.0146 \\
(0.950)\end{array}$ & $\begin{array}{c}-0.5782 \\
(0.191)\end{array}$ & $\begin{array}{l}0.1824 \\
(0.207)\end{array}$ & $\begin{array}{l}-0.0283 \\
(0.908)\end{array}$ & $\begin{array}{l}-0.4271 \\
(0.255)\end{array}$ \\
\hline \multicolumn{7}{|l|}{$\begin{array}{l}\text { Education b.c. } \\
\text { GCSE/vocational) }\end{array}$} \\
\hline Postgraduate & $\begin{array}{l}-0.4549 \\
(0.003)\end{array}$ & $\begin{array}{l}0.1628 \\
(0.507)\end{array}$ & $\begin{array}{l}0.9325 \\
(0.014)\end{array}$ & $\begin{array}{l}-0.5219 \\
(0.002)\end{array}$ & $\begin{array}{l}0.2049 \\
(0.422)\end{array}$ & $\begin{array}{l}0.5509 \\
(0.139)\end{array}$ \\
\hline Bachelor & $\begin{array}{l}-0.3732 \\
(0.004)\end{array}$ & $\begin{array}{l}-0.0137 \\
(0.950)\end{array}$ & $\begin{array}{l}0.4480 \\
(0.212)\end{array}$ & $\begin{array}{l}-0.4108 \\
(0.004)\end{array}$ & $\begin{array}{l}-0.1070 \\
(0.644)\end{array}$ & $\begin{array}{l}0.4779 \\
(0.159)\end{array}$ \\
\hline Professional & $\begin{array}{l}-0.0364 \\
(0.782)\end{array}$ & $\begin{array}{l}0.1324 \\
(0.547)\end{array}$ & $\begin{array}{l}-0.0143 \\
(0.971)\end{array}$ & $\begin{array}{l}-0.1706 \\
(0.243)\end{array}$ & $\begin{array}{l}0.0145 \\
(0.950)\end{array}$ & $\begin{array}{l}-0.0558 \\
(0.881)\end{array}$ \\
\hline A-level & $\begin{array}{l}-0.0334 \\
(0.831)\end{array}$ & $\begin{array}{l}-0.1908 \\
(0.489)\end{array}$ & $\begin{array}{l}0.6129 \\
(0.132)\end{array}$ & $\begin{array}{l}-0.2722 \\
(0.102)\end{array}$ & $\begin{array}{l}-0.4062 \\
(0.158)\end{array}$ & $\begin{array}{l}0.3738 \\
(0.335)\end{array}$ \\
\hline No formal & $\begin{array}{l}0.2428 \\
(0.344)\end{array}$ & $\begin{array}{l}\mathbf{0 . 7 1 4 4} \\
(0.048)\end{array}$ & $\begin{array}{l}1.0264 \\
(0.067)\end{array}$ & $\begin{array}{l}-0.1088 \\
(0.688)\end{array}$ & $\begin{array}{l}0.4909 \\
(0.180)\end{array}$ & $\begin{array}{l}0.3198 \\
(0.609)\end{array}$ \\
\hline \multicolumn{7}{|l|}{ Owner's Age } \\
\hline Age (centred) & $\begin{array}{l}\mathbf{0 . 0 1 1 1} \\
(0.022)\end{array}$ & $\begin{array}{l}0.0044 \\
(0.566)\end{array}$ & $\begin{array}{l}-0.0087 \\
(0.442)\end{array}$ & $\begin{array}{l}0.0087 \\
(0.089)\end{array}$ & $\begin{array}{l}0.0057 \\
(0.476)\end{array}$ & $\begin{array}{l}-0.0158 \\
(0.185)\end{array}$ \\
\hline Age (centred) squared & $\begin{array}{l}0.0000 \\
(0.991)\end{array}$ & $\begin{array}{l}0.0003 \\
(0.543)\end{array}$ & $\begin{array}{l}0.0010 \\
(0.160)\end{array}$ & $\begin{array}{l}-0.0002 \\
(0.609)\end{array}$ & $\begin{array}{l}0.0001 \\
(0.766)\end{array}$ & $\begin{array}{l}0.0005 \\
(0.501)\end{array}$ \\
\hline Constant & $\begin{array}{l}2.3506 \\
(0.000)\end{array}$ & $\begin{array}{r}-0.6950 \\
(0.032)\end{array}$ & $\begin{array}{l}-2.6670 \\
(0.000)\end{array}$ & $\begin{array}{l}2.2445 \\
(0.000)\end{array}$ & $\begin{array}{l}-0.8416 \\
(0.013)\end{array}$ & $\begin{array}{l}-2.4926 \\
(0.000)\end{array}$ \\
\hline$N$ & 4589 & & & 4589 & & \\
\hline $\begin{array}{l}\text { LR-test (Null of } \\
\text { constant probability) }\end{array}$ & 469.1 & [78] & $(0.000)$ & 664.7 & [78] & $(0.000)$ \\
\hline$R^{2}$ & 0.065 & & & 0.096 & & \\
\hline $\begin{array}{l}\text { LR-test (Website } \\
\text { variables) }\end{array}$ & 48.7 & [6] & $(0.000)$ & 48.9 & [6] & $(0.000)$ \\
\hline
\end{tabular}

Notes: p-values in parentheses 
Table 5 - Standardised Canonical Discriminant Function Coefficients for Four Categories of SMEs, Website usage measured directly

\begin{tabular}{|c|c|c|c|c|c|c|}
\hline \multirow{2}{*}{$\frac{\text { Performance Measure }}{\text { Function }}$} & \multicolumn{3}{|c|}{ Profits Growth } & \multicolumn{3}{|c|}{ Sales Growth } \\
\hline & 1 & 2 & 3 & 1 & 2 & 3 \\
\hline Turnover £500K+ & 0.281 & 0.154 & -0.020 & 0.216 & 0.071 & 0.072 \\
\hline Turnover $<£ 100 \mathrm{~K}$ & -0.281 & 0.030 & -0.172 & -0.188 & -0.165 & 0.021 \\
\hline Firm age $<4$ years & 0.416 & 0.566 & -0.185 & 0.554 & -0.402 & 0.800 \\
\hline Firm age 10 to 19 years & & & & -0.365 & 0.181 & 0.957 \\
\hline Firm age $20+$ years & -0.213 & -0.003 & -0.036 & -0.422 & 0.068 & 0.495 \\
\hline No Website & -0.275 & 0.128 & 0.210 & -0.204 & -0.253 & -0.010 \\
\hline Active Website & 0.170 & -0.310 & -0.407 & 0.158 & 0.303 & -0.003 \\
\hline $\begin{array}{l}\text { Postgraduate } \\
\text { Qualifications }\end{array}$ & 0.340 & -0.197 & 0.296 & 0.187 & 0.327 & -0.045 \\
\hline Graduate Qualifications & 0.222 & 0.087 & 0.158 & 0.138 & 0.085 & -0.355 \\
\hline Primary Industries & 0.261 & 0.013 & 0.376 & & & \\
\hline Manufacturing & 0.391 & -0.416 & 0.383 & 0.124 & 0.508 & 0.130 \\
\hline Hotels and Restaurants & & & & -0.141 & 0.154 & 0.034 \\
\hline Financial Services & 0.193 & 0.444 & 0.481 & & & \\
\hline Business Services & 0.477 & 0.029 & -0.051 & 0.275 & 0.264 & 0.142 \\
\hline $\begin{array}{l}\text { Education, Health and } \\
\text { Social Services }\end{array}$ & 0.192 & 0.239 & -0.280 & & & \\
\hline Eigenvalue & 0.069 & 0.017 & 0.004 & 0.115 & 0.022 & 0.003 \\
\hline$\%$ of Variance & 76.6 & 18.9 & 4.5 & 82.4 & 15.5 & 2.1 \\
\hline Canonical Correlation & 0.254 & 0.130 & 0.064 & 0.321 & 0.146 & 0.054 \\
\hline Group Centroids & 1 & 2 & 3 & 1 & 2 & 3 \\
\hline $\begin{array}{l}\text { Low Growth No } \\
\text { Innovation }\end{array}$ & -0.143 & -0.017 & -0.005 & -0.174 & -0.015 & -0.006 \\
\hline Growth No Innovation & 0.381 & 0.236 & 0.022 & 0.714 & -0.195 & 0.026 \\
\hline Low Growth Innovator & 0.454 & -0.177 & -0.196 & 0.291 & 0.437 & 0.123 \\
\hline Growth Innovator & 0.910 & -0.538 & 0.263 & 0.854 & 0.425 & -0.275 \\
\hline Functions & $1-3$ & $2 \& 3$ & 3 & $1-3$ & $2 \& 3$ & 3 \\
\hline Wilks Lambda & 0.916 & 0.979 & 0.996 & 0.875 & 0.976 & 0.997 \\
\hline$\chi^{2}$ & 496.8 & 118.8 & 23.1 & 752.5 & 137.5 & 16.2 \\
\hline d.f & [39] & [24] & [11] & [36] & [22] & [10] \\
\hline$p$-value & $(0.000)$ & $(0.000)$ & $(0.017)$ & $(0.000)$ & $(0.000)$ & $(0.093)$ \\
\hline
\end{tabular}


Table 6 - Standardised Canonical Discriminant Function Coefficients for Four Categories of SMEs, Website usage measured indirectly via e-commerce sales

\begin{tabular}{|c|c|c|c|c|c|c|}
\hline \multirow{2}{*}{$\frac{\text { Performance Measure }}{\text { Function }}$} & \multicolumn{3}{|c|}{ Profits Growth } & \multicolumn{3}{|c|}{ Sales Growth } \\
\hline & 1 & 2 & 3 & 1 & 2 & 3 \\
\hline Turnover £500K+ & 0.302 & 0.123 & 0.008 & 0.228 & 0.094 & 0.026 \\
\hline Turnover $<£ 100 \mathrm{~K}$ & -0.367 & 0.083 & -0.146 & -0.252 & -0.254 & 0.110 \\
\hline Firm age $<4$ years & 0.483 & 0.555 & -0.223 & 0.556 & -0.284 & 0.882 \\
\hline Firm age 10 to 19 years & -0.231 & 0.018 & -0.106 & -0.441 & 0.222 & 0.894 \\
\hline $\begin{array}{c}\text { Firm age } 20 \text { or more } \\
\text { years }\end{array}$ & -0.054 & 0.244 & 0.677 & -0.461 & 0.050 & 0.575 \\
\hline No e-commerce sales & 0.270 & -0.179 & 0.008 & 0.177 & 0.474 & -0.034 \\
\hline $\begin{array}{l}\text { High e-commerce }>10 \% \\
\text { sales }\end{array}$ & 0.361 & -0.120 & 0.213 & 0.206 & 0.307 & 0.061 \\
\hline $\begin{array}{l}\text { Postgraduate } \\
\text { Qualifications }\end{array}$ & 0.253 & 0.091 & 0.112 & 0.159 & 0.085 & -0.212 \\
\hline Graduate Qualifications & 0.211 & 0.034 & 0.214 & 0.228 & 0.094 & 0.026 \\
\hline Primary Industries & 0.404 & -0.446 & 0.393 & & & \\
\hline Manufacturing & 0.160 & 0.449 & 0.299 & 0.128 & 0.559 & 0.141 \\
\hline Hotel and Restaurants & & & & -0.165 & 0.029 & 0.246 \\
\hline Financial Services & -0.231 & 0.018 & -0.106 & & & \\
\hline Business Services & 0.497 & -0.161 & -0.100 & 0.278 & 0.379 & 0.109 \\
\hline $\begin{array}{l}\text { Education, Health and } \\
\text { Social Services } \\
\end{array}$ & 0.239 & 0.150 & -0.323 & & & \\
\hline Eigenvalue & 0.064 & 0.019 & 0.006 & 0.111 & 0.023 & 0.003 \\
\hline$\%$ of Variance & 72.0 & 21.1 & 6.92 & 80.9 & 16.7 & 2.4 \\
\hline Canonical Correlation & 0.246 & 0.136 & 0.078 & 0.316 & 0.150 & 0.058 \\
\hline Group Centroids & 1 & 2 & 3 & 1 & 2 & 3 \\
\hline $\begin{array}{l}\text { Low Growth No } \\
\text { Innovation }\end{array}$ & -0.143 & -0.015 & 0.006 & -0.174 & -0.020 & -0.006 \\
\hline Growth No Innovation & 0.366 & 0.242 & 0.015 & 0.697 & -0.178 & 0.033 \\
\hline Low Growth Innovator & 0.446 & -0.235 & -0.217 & 0.231 & 0.465 & 0.120 \\
\hline Growth Innovator & 0.766 & -0.481 & 0.352 & 0.776 & 0.385 & -0.291 \\
\hline Functions & $1-3$ & $2 \& 3$ & 3 & $1-3$ & $2 \& 3$ & 3 \\
\hline Wilks Lambda & 0.917 & 0.976 & 0.994 & 0.877 & 0.974 & 0.997 \\
\hline$\chi^{2}$ & 398.4 & 113.5 & 28.3 & 601.5 & 118.9 & 15.3 \\
\hline d.f & {$[39]$} & {$[24]$} & {$[11]$} & {$[33]$} & {$[20]$} & {$[9]$} \\
\hline$p$-value & $(0.000)$ & $(0.000)$ & $(0.003)$ & $(0.000)$ & $(0.000)$ & $(0.084)$ \\
\hline
\end{tabular}


Table A1 - Summary of Dependent Variables

\begin{tabular}{cccc}
\hline & & Website Usage & Sample \\
Growth & Low Growth No Innovation & $75.8 \%$ & $\begin{array}{c}\text { E-commerce } \\
\text { Sales Sample }\end{array}$ \\
based on & Growth No Innovation & $15.4 \%$ & $74.8 \%$ \\
profits & Low Growth Innovator & $6.6 \%$ & $16.0 \%$ \\
& Growth Innovator & $2.1 \%$ & $6.8 \%$ \\
& & & $2.4 \%$ \\
Growth & Low Growth No Innovation & $77.8 \%$ & $76.7 \%$ \\
based on & Growth No Innovation & $13.5 \%$ & $14.1 \%$ \\
sales & Low Growth Innovator & $6.3 \%$ & $6.6 \%$ \\
& Growth Innovator & $2.4 \%$ & $2.6 \%$ \\
\hline
\end{tabular}




\begin{tabular}{|c|c|c|c|}
\hline & & $\begin{array}{l}\text { Website } \\
\text { Usage } \\
\text { Sample }\end{array}$ & $\begin{array}{l}\text { E-commerce } \\
\text { Sales Sample }\end{array}$ \\
\hline \multirow{6}{*}{$\begin{array}{l}\text { Type of } \\
\text { website } \\
\text { present }\end{array}$} & No Website & $25.7 \%$ & $21.8 \%$ \\
\hline & Basic contact information & $19.2 \%$ & $18.8 \%$ \\
\hline & Advertise products & $37.3 \%$ & $38.5 \%$ \\
\hline & Sell on-line & $14.0 \%$ & $16.0 \%$ \\
\hline & Link to suppliers & $1.2 \%$ & $1.2 \%$ \\
\hline & Sell online and link to suppliers & $2.6 \%$ & $2.9 \%$ \\
\hline \multirow{3}{*}{$\begin{array}{l}\text { Percentage of } \\
\text { sales through } \\
\text { e-commerce }\end{array}$} & No sales & $59.5 \%$ & $59.4 \%$ \\
\hline & 1 to 10 percent of sales & $21.1 \%$ & $21.1 \%$ \\
\hline & 11 percent of sales or more & $19.4 \%$ & $19.5 \%$ \\
\hline \multirow{3}{*}{ Turnover } & Less than $£ 100,000$ & $43.0 \%$ & $42.6 \%$ \\
\hline & $£ 100,000$ to $£ 500,000$ & $37.9 \%$ & $38.1 \%$ \\
\hline & More than $£ 500,000$ & $19.1 \%$ & $19.4 \%$ \\
\hline \multirow{4}{*}{ Firm Age } & Less than 4 years & $19.4 \%$ & $19.8 \%$ \\
\hline & 4 to 9 years & $31.8 \%$ & $32.0 \%$ \\
\hline & 10 to 19 years & $28.5 \%$ & $29.0 \%$ \\
\hline & 20 years or older & $20.3 \%$ & $19.2 \%$ \\
\hline \multirow{11}{*}{ Industry } & Urban location & $63.4 \%$ & $63.5 \%$ \\
\hline & Agriculture and extractive & $14.7 \%$ & $14.4 \%$ \\
\hline & Manufacturing & $10.7 \%$ & $11.1 \%$ \\
\hline & Transport and Utilities & $6.2 \%$ & $6.0 \%$ \\
\hline & Hotels and Restaurants & $6.5 \%$ & $5.8 \%$ \\
\hline & Financial, \& Real Estate & $6.0 \%$ & $6.3 \%$ \\
\hline & Business Services & $19.8 \%$ & $21.3 \%$ \\
\hline & Health, Educ' \& Social Services & $6.0 \%$ & $5.7 \%$ \\
\hline & Consumer and Personal Services & $5.4 \%$ & $5.1 \%$ \\
\hline & Wholesale and Retail & $21.6 \%$ & $21.2 \%$ \\
\hline & Others & $3.0 \%$ & $3.2 \%$ \\
\hline \multirow{3}{*}{$\begin{array}{l}\text { Gender of } \\
\text { owners }\end{array}$} & Majority Male & $50.5 \%$ & $51.6 \%$ \\
\hline & Equal ownership & $34.8 \%$ & $34.7 \%$ \\
\hline & Majority Female & $14.8 \%$ & $13.7 \%$ \\
\hline \multirow{6}{*}{ Education } & Postgraduate & $10.7 \%$ & $11.9 \%$ \\
\hline & Bachelor & $21.9 \%$ & $23.8 \%$ \\
\hline & Professional & $26.9 \%$ & $26.6 \%$ \\
\hline & A-level & $13.0 \%$ & $13.2 \%$ \\
\hline & GCSE/Vocational & $21.4 \%$ & $19.5 \%$ \\
\hline & No formal & $6.0 \%$ & $5.1 \%$ \\
\hline \multirow[t]{3}{*}{ Owners Age } & Mean & 51.0 & 50.9 \\
\hline & Standard Deviation & 10.0 & 10.0 \\
\hline & N & 5660 & 4589 \\
\hline
\end{tabular}

